Int. J. Dev. Biol. 51: 663-678 (2007)

doi: $10.1387 / \mathrm{ijdb} .072367 \mathrm{bf}$

\title{
Molecular evolution of the vertebrate mechanosensory cell and ear
}

\author{
BERND FRITZSCH*, KIRK W. BEISEL, SARAH PAULEY and GARRETT SOUKUP \\ Creighton University, Dept. of Biomedical Sciences, Omaha, NE, USA
}

\begin{abstract}
The molecular basis of mechanosensation, mechanosensory cell development and mechanosensory organ development is reviewed with an emphasis on its evolution. In contrast to eye evolution and development, which apparently modified a genetic program through intercalation of genes between the master control genes on the top (Pax6, Eya1, Six 1) of the hierarchy and the structural genes (rhodopsin) at the bottom, the as yet molecularly unknown mechanosensory channel precludes such a firm conclusion for mechanosensors. However, recent years have seen the identification of several structural genes which are involved in mechanosensory tethering and several transcription factors controlling mechanosensory cell and organ development; these warrant the interpretation of available data in very much the same fashion as for eye evolution: molecular homology combined with potential morphological parallelism. This assertion of molecular homology is strongly supported by recent findings of a highly conserved set of microRNAs that appear to be associated with mechanosensory cell development across phyla. The conservation of transcription factors and their regulators fits very well to the known or presumed mechanosensory specializations which can be mostly grouped as variations of a common cellular theme. Given the widespread distribution of the molecular ability to form mechanosensory cells, it comes as no surprise that structurally different mechanosensory organs evolved in different phyla, presenting a variation of a common theme specified by a conserved set of transcription factors in their cellular development. Within vertebrates and arthropods, some mechanosensory organs evolved into auditory organs, greatly increasing sensitivity to sound through modifications of accessory structures to direct sound to the specific sensory epithelia. However, while great attention has been paid to the evolution of these accessory structures in vertebrate fossils, comparatively less attention has been spent on the evolution of the inner ear and the central auditory system. Recent advances in our molecular understanding of ear and brain development provide novel avenues to this neglected aspect of auditory neurosensoy evolution.
\end{abstract}

KEY WORDS: ear evolution, hair cell evolution, otic placode evolution, auditory system evolution

\section{Introduction}

Next to the eye, the ear, with its ability to convert sound into meaningful signals that help mediate spoken communications, is the most important sense for human social interactions. Understanding how these two senses evolved and become the dominant input for everyday interactions is thus an important aspect for evolution of human. In the visual system, two insights have helped stimulate molecular evolutionary research:

A) A small set of genes (e.g., Pax6, Atoh7/atonal, Eya1) produce essential transcription factors for the development of eyes no matter what shape or form (Gehring, 2005).

B) All rhodopsins mediating photic stimulation are related at the molecular level thus aligning diversely shaped photoreceptors through a common molecular basis (Arendt et al., 2004).

Thus, it has been proposed that molecular evolution of receptor, receptor cell and receptor organ all are tightly interrelated through a nested set of conserved genes necessary to specify the expression of rhodopsins in receptor cells and to ensure that the cells are properly placed within an organ to direct light to the cells that contain the highest concentration of rhodopsin. This view of photoreceptor evolution reflects the simple fact that even single celled organisms have specialized photoreceptor areas and that multicellular organisms have photic reception without specialized

Abbreviations used in this paper: bHLH, basic helix-loop-helix.

\footnotetext{
*Address correspondence to: Bernd Fritzsch, Ph.D. Creighton University, Dept of Biomedical Sciences, Omaha, NE, 68178, USA. Fax: +1-402-280-5556. e-mail: Fritzsch@Creighton.edu
} 
cells or with specialized cells that do not form a distinct organ. Subsequent evolution of the various eye types may have occurred by the modification of an original genetic program through intercalation of genes between the master control genes on the top of the hierarchy and the structural genes like rhodopsin at the bottom (Gehring, 2005) or other means (Alonso and Wilkins, 2005). In essence, what appears to be panoptical diversity of structurally dissimilar eyes may in fact be permutations of an ancient theme. In fact, some of the molecules associated with eyes are also conserved in ears (Fritzsch et al., 2005b). Most importantly, despite an emerging and possibly unifying molecular evolutionary theme for these major sensory systems, shear structural diversity has been viewed as an insurmountable obstacle to align ear evolution across phyla.

In part this is so because evolution of terrestrial hearing has long been investigated from the point of view of evolution of three middle ear ossicles and the tympanic membrane owing to readily available but difficult to interpret fossils (Brazeau and Ahlberg, 2006, Clack, 2002, Fritzsch, 1992, Fritzsch, 1999, Massa et al., 2006). However, the evolutionary changes in the inner ear that allow the selective perception of sound in a specialized organ have received much less attention despite the fact that any adaptive change in the middle ear requires the prior existence of an inner ear to make use of those changes in terms of sound perception (Fritzsch, 1992, Fritzsch et al., 2006c). This lack of consideration of the inner ear relates to the near complete absence of fossil evidence of inner ear evolution, the contentious interpretation of existing data on extant taxa, the incomplete understanding and diverse interpretation of taxonomic relationships of key species and an incomplete understanding and implementation of the physics of sound in water and on land toward interpretation of the putative receivers. This review will focus exclusively on the inner ear aspect of vertebrate ear evolution, highlighting the necessary developmental change required to alter existing molecular programs to generate a novel, adaptive outcome.

Logically, the starting point for considerations on the evolution of sound perception has to be the hair cell and its mechanotransduction apparatus, the stereocilia with their tip links to open and close a still unknown channel. This channel allows ionic currents to change the resting potential to reflect sound mediated stimulations. We will first review the evolution of mechanosensation at the molecular and cellular level. Accessory structures and grouping of hair cells into organs that permit perception of distinct stimuli is the next logical step in evolution and the molecular evidence of how this might have happened will be reviewed next. Among vertebrates, it has long been recognized that a purely vestibular ear, dedicated to the perception of gravistatic and angular stimuli, predates the evolution of whole epithelia or their parts to dedicated sound receivers. We will therefore next review the evolution of the vertebrate ear, including the molecular evolution of placode formation and the molecular basis for morphogenesis to form the vertebrate labyrinth. Finally, evolution of an auditory system requires alterations in the developmental program of the ear to generate a sensory epithelium dedicated to sound, a set of sensory neurons dedicated to conducting the sound elicited information to the brain and a central target area dedicated to the reception of sound. In this part of our analysis we will review how a separate epithelium can arise, how it can be transformed into a sound perceiving epithelium through specific interactions with the adjacent periotic mesoderm and how separate sensory neurons can be generated and specified to project to a different central target than nearby vestibular neurons.

\section{Molecular evolution suggests conservation of teth- ers, but not of channels}

Mechanosensation refers to a mechanical stimulus-driven opening and closing of an ion channel to change the resting potential of the sensory cell. Despite extensive efforts, the mechanosensory equivalent of the phototransduction protein rhodopsin has not yet been found. Molecular evolution of mechanosensation thus cannot be understood the same way rhodopsin evolution contributes to understanding vision (Arendt et al., 2004, Gehring, 2005). Comparison across phyla shows that mechanosensation comes in two basic principles:

1) Stretch within the membrane opens a channel.

2) Stretch on intracellular and/or extracellular tethers open a channel (Fig. 1).

Obviously, membrane stretch exists already in unicellular organisms whereas mechanosensation with tethers requires cellular specializations such as specific stiffness inside a cell (assembly of microtubules, intermediate filaments or actin filaments) or connections outside a cell (such as other cells, other protruding parts of the same cell or extracellular matrix) to be properly organized (Fig. 1). Interestingly, some of the molecules now known to be associated with such tethers show some degree of conservation. For example, the rare myosin VIla is associated with hearing loss in both vertebrates and flies (Todi et al., 2005), VLGR mutations cause hearing loss in humans and the gene exists in many Deuterostomes including sea urchins and protocadherins are found in most metazoan phyla (Burke et al., 2006, Sodergren et al., 2006).

In contrast to this apparent conservation and function as a part of the mechanotransduction process of molecules known or suspected in tethering, there is no candidate gene representing a conserved channel. Indeed, all candidates of putative vertebrate channel genes that have been mutated to date have resulted in minor effects but no loss of mechanosensation (Kwan et al., 2006, Lin and Corey, 2005). The only known channel genes are those of the worm, C. elegans (O'Hagan et al., 2005). These genes belong to the ENaC/BNaC family of genes, but have no orthologue in vertebrates. Nevertheless, the most likely candidates for mechanosensory channels are among the ENaC/BNaC and Trp channel genes (Sukharev and Corey, 2004). Detailed sequence comparisons using existing databases show only limited conservation of a few genes across vertebrates that all share the same mechanosensory cell, the hair cell (Beisel et al., 2007). Indeed, one gene identified as being crucial in mechanosensory function of zebrafish does not exist in mammals (Gillespie et al., 2005, Sidi et al., 2003). Combined, these data suggest that mechanosensory channel proteins might not be conserved and might actually be organized of several different components that form a heteromultimer. Such multimers with variable functions were recently described for the TRPV thermosensitive channels (Cheng et al., 2007). If this is also true for 
Fig. 1. Various channels that respond to changes in turgor resulting in stretch of the membranes (double arrow in A, B) have been found in single cell organisms. Detailed models of the pentameric mechanosensitive channel of bacteria suggests an iris-like opening upon tension acting in the plane of the membrane (B). It is possible that such mechanosensitive channels were modified in the unicellular ancestor of metazoans through extracellular or intracellular matrix attachments to provide increased sensitivity for shearing forces. Molecular evidence suggests that, across metazoans, only members of two cation channel families are candidates for mechanosensitive channels (C,D). It thus remains possible that metazoan ancestors evolved either or both families for specific properties that allow increased sensitivity to detect mechanical stimulations. What such properties could be remains unknown in the absence of any model of sensitive mechanosensory channel in any metazoan taxon. Mutational analysis has identified several genes that are essential for the function in nematodes (C) and vertebrates (D). In nematodes, fine touch is lost when either specific molecules of the extracellular matrix to which the channel is anchored are lost (Mec-1, 5, 9), or if specific components of the channel complex are lost (Mec-2,
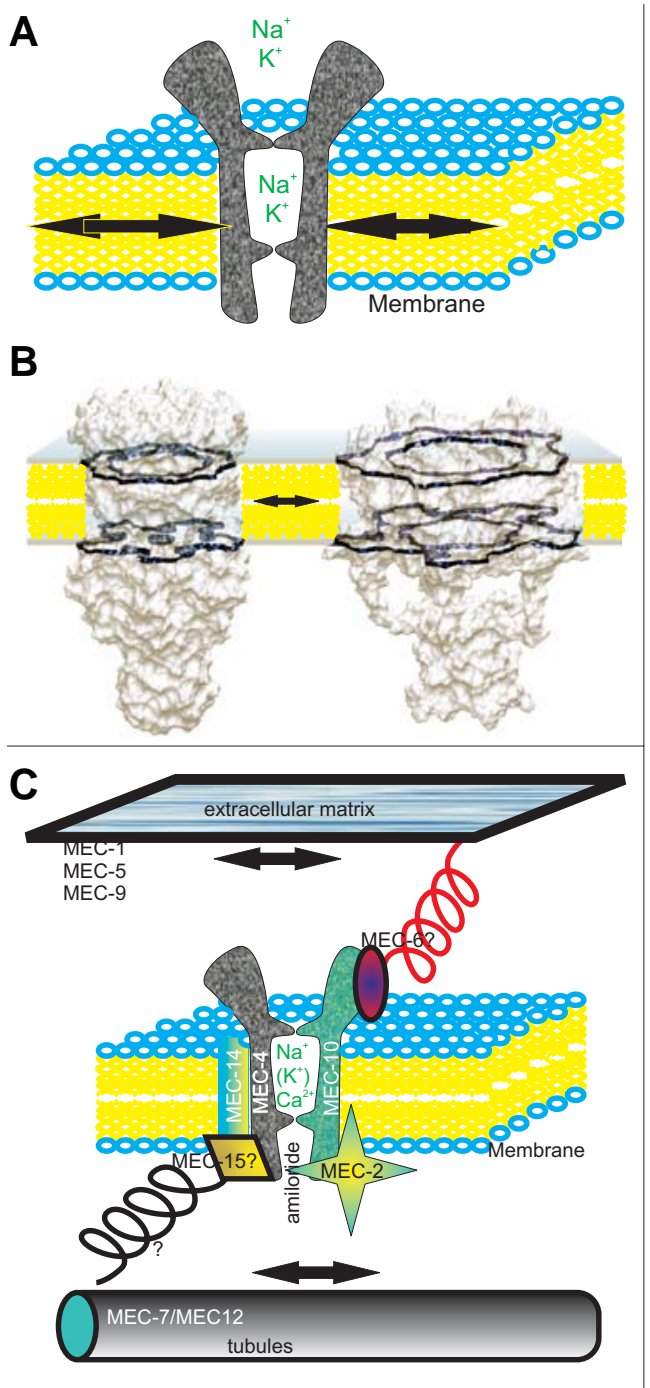

D

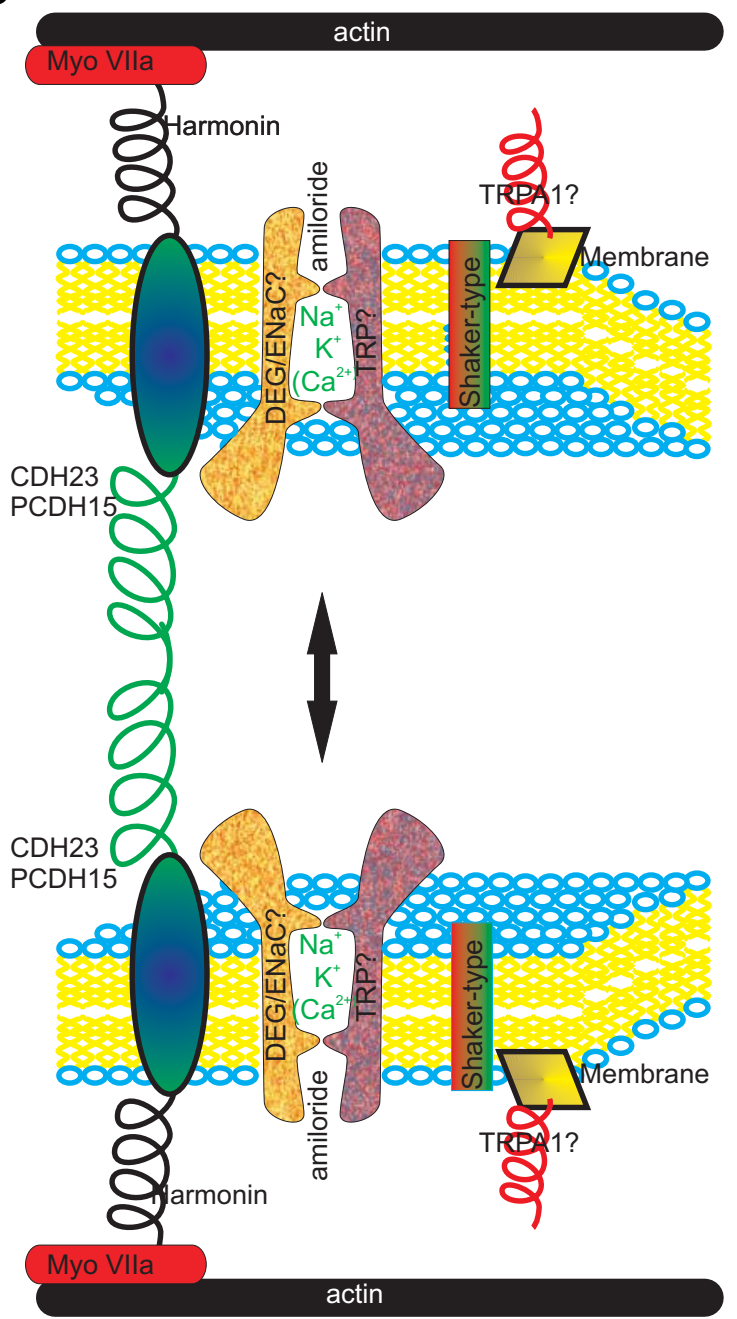

$4,10,14)$. However, loss to the intracellular tubules (Mec-7, 12) may lead only to a reduced sensitivity, not a complete loss of sensation. In contrast, in vertebrates there is no extracellular matrix or cuticular connection. Instead, two stereocilia are interconnected presumably by Cdh23 that is hypothesized to be anchored to MyoVIla via harmonin. Loss of any of these genes results in deafness indicating that in vertebrates mechanosensation requires relative movement against the actin core of the stereocilia. Additional connections exist between Cdh23 and Myo1c but no knockout data support the claimed function as an adaptor. It is speculated that MyoVIla transports the still unknown amiloride sensitive mechanosensory channel to the tip but it is unclear whether this connection remains past development. In nematodes at least two essential subunits of the mechanosensitive channel are known whereas it is not clear what the vertebrate channel is composed of. Certain candidates have been excluded as mutants in, for example, TRPA1 do hear excluding an essential role of this protein in mechanosensory transduction. Note that both nematode and vertebrate have a shaker-type channel associated with the mechanosensory channel, but details are unknown. Modified after (Bryant et al., 2005, Chiang et al., 2004, Syntichaki and Tavernarakis, 2004).

mechanosensory channels, eliminating a single gene will only result in measurable effects if the gene happens to provide the major or only component of the multimeric mechanosensory channel.

It is thus likely that the only aspect that is conserved across phyla for such channel proteins is an ability to attach to the apparently conserved tethering proteins. The constraints imposed by this basic principle are few and thus would allow for a multitude of cellular solutions to ensure that the membrane bound channel can be driven by mechanical stimuli. Compara- tive analysis of mechanosensory cells and organs thus show, expectedly, a rich variety of specializations suspected or known to function in the context of mechanosensation. The coordinated expression of apparently multiple genes in a given mechanosensory cell to assemble the mechanosensory complex requires higher level transcription factors that have the capacity to regulate the spatio-temporal expression of all those proteins within a cell and, in case of cell-cell connections, between neighboring cells. We therefore will next analyze the evolution of cellular transcription factors known or suspected 
to play a role in this process across phyla.

\section{Conserved transcription factors regulate mechano- sensory cell development}

Cellular differentiation of neurons and sensory cells requires bHLH genes (Bertrand et al., 2002, Kageyama et al., 2005) a highly conserved set of genes that evolved in single cell organisms where they functioned in regulating metabolism (Simionato et al., 2007). Two of those bHLH gene families, the achaete-scute and the atonal family of genes appear to be associated with mechano-, chemo- and photoreceptor development across phyla. Of these genes, the atonal family of genes is more closely associated with photo- and mechanosensation (Fig. 2). Specifically, atonal genes evolved with multicellular organisms (Seipel et al., 2004) and are among a few protein coding genes that are structurally and functionally conserved to the extent that orthologues of fly and mouse, atonal and Atoh1, can be mutually exchanged and show compensatory function in distant organisms (Wang et al., 2002). The bHLH family shows expansion consistent with the requirement of additional members to regulate differentiation of developmentally and physically connected cells in vertebrates, the sensory neurons and hair cells (Fritzsch et al., 2000, Fritzsch et al., 2006b). The best known downstream factor of atonal genes is Barlh, a gene necessary to maintain hair cells which are progressively lost in null mutants $\mathrm{A}(\mathrm{Li}$ et al., 2002). It remains unclear how Atoh 1 is affecting overall development of hair cells, but only undifferentiated precursors form in Atoh1 null mice that eventually degenerate (Bermingham et al., 1999, Chen et al., 2002, Fritzsch et al., 2005a). Likewise, atonal null mutant flies lose most of their mechanosensory proprioception, including hearing (Caldwell and Eberl, 2002). Atonal-like genes seem to have a somewhat broader function in coelenterates where they specify sensory neurons as well as myosensory cells (Seipel et al., 2004).

In addition to bHLH genes, Pou domain factors are essential and conserved transcription factors for cellular differentiation, including the hair cells of the ear (Erkman et al., 1996, O'Brien and Degnan, 2002) which initially form but soon degenerate in Pou4f3 null mice (Hertzano et al., 2004, Xiang et al., 2003). Downstream to Pou4f3 is another essential gene for sensory development, the zinc-finger protein Gfi1 (Hertzano et al., 2004, Wallis et al., 2003). Hair cells form in the absence of Gfit but degenerate over time (Hertzano et al., 2004). The orthologue of Gfit in insects (senseless) is needed for differentiation of sensory cells and can even substitute for atonal in insects (Jafar-Nejad et al., 2003). Interactions of senseless and bHLH genes appear to function as a binary switch to promote or suppress sensory fate and thus to enhance other associated processes such as delta-notch lateral inhibition (Daudet and Lewis, 2005, Kageyama et al., 2007). It appears that mechanosensory cell development is governed by a nested expression of transcription factors that cooperate to ensure complete differentiation and maintenance of such cells. Neither the individual functions nor interactions of transcription factors required to achieve the desired outcome are completely understood (Fritzsch et al., 2006a, Kelley, 2006a). However, it is clear that these genes are ancestral to triploblasts and possibly metazoans and this may form the basis of mechanosensory cell evolution.

Despite the clear importance of such transcription factors for mechanosensory cell development, their regulation remains unclear except that Pou4f3 regulates Gfi1 and that Atoh1 regulates Barlh. It appears that in mammals Sox2 regulates, directly or indirectly, expression of Atoh1 as no Atoh1 expression has been reported in Sox2hypomorphs (Kiernan et al., 2005). How Sox2 expression is regulated, however, remains unclear despite tremendous insights into the Sox2 promoter region (Uchikawa et al., 2003). Moreover, in insects there is no evidence for the expression of Sox genes in neurosensory precursors (McKimmie et al., 2005), suggesting that Sox2 in the PNS is a vertebrate acquisition that may relate to the clonal expansion of neurosensory precursors required to form large sensory arrays such as the sensory epithelia of the ear (Pauley et al., 2005). In contrast, flies seem to use EGFr for somewhat similar clonal expansion (Eberl and Boekhof-Falk, this volume). How Pou4f3 expression is regulated is even less
Fig. 2. The evolution of the atonal and neurogenin families of bHLH genes (A) and the evolution of the mechanosensory cells and their associated neurons that require those family members for cellular development (B) is shown. Note that atonal and achaete/scute family evolved already in coelenterates. However, the neurogenin family may have evolved only in triploblasts. Evolution of a pair of cells (a secondary mechanosensory cell without an axon and a mechanosensory neuron connecting the cell to the brain) evolved out of a primary mechanosensory cell (with an axon) only after the neurogenin family had evolved. Whether atonal family members are always associated with mechanosensory cells in triploblasts and whether neurons associated with mechanosensory cells in other triploblasts require neurogenin for development is unknown. Modified after (Fritzsch and Beisel, 2004, Furlong and Graham, 2005).
A
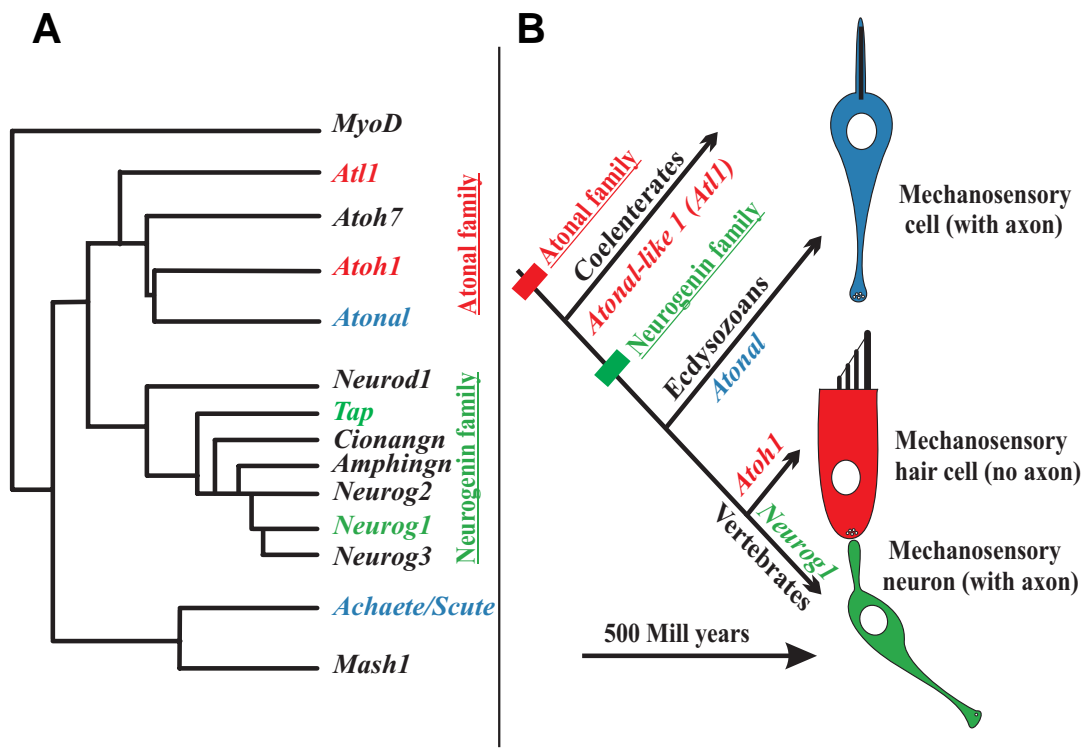
clear and it remains equally unclear how independent its expression is of Atoh 1 .

In addition to the regulation of molecular components that possibly govern the organization of the mechanosensory apparatus, these early expressed transcription factors also need to ensure that a mechanosensory cell develops through suppression of alternative fates such as supporting cell or generalized ectoderm. It appears that the former is predominantly regulated through the ubiquitous delta/notch system for lateral inhibition of cell fate (Daudet and Lewis, 2005, Fritzsch et al., 2006a, Kageyama et al., 2007, Lanford and Kelley, 2005) whereas the latter might require the presence of specific inhibitors of transcription and/or translation to eliminate mRNA that favors an alternate fate. In addition to hair cell specific mRNA for transcription factors that positively regulate mechanosensory cell development, the microRNAs (miRNAs) known to be selectively expressed in mechanosensory cells (Weston et al., 2006) can repress specific existing mRNAs and thus might ensure a secure transition from one presumptive cell fate to another. Most importantly, these mechanisms likely evolved prior to the formation of mechanosensory organs. It is conceivable that, in analogy to the evolution of photoreceptor organs, a rich variety of organs can evolve using the highly conserved set of genes currently characterized for mechanosensory development across phyla (Fritzsch and Beisel, 2004, Todi et al., 2005). Among these conserved set of genes, miRNAs are the most conserved. Indeed, not a single base may be different across entire phyla. Such conservation might eventually enable us to understand the molecular evolution of mechanosensory cell development through an understanding of the genes targeted for repression by miRNAs. Such genes are expected to antagonize Atoh1/atona/signaling and stabilize the default development as ectodermal/skin cells.

Cellular transitions in fate will bear the risk for cells that novel gene expression patterns interfere with the existing profile. Minimizing such risk requires a molecular means to stabilize precursors from cell death to enable such transitions. A set of molecules recently identified to have this capacity are the Pax genes (Bouchard et al., 2002, Torban et al., 2000). As with eye development, Pax2/5/8 expression has been associated with mechanosensory development across phyla (Czerny et al., 1997, Kozmik et al., 2003), possibly providing this
Fig. 3. Evolution of mechanosensory cells. Kinocilia (red) and microvilli (light blue) of known or suspected mechanosensory cells in various eukaryotic unicellular (1) and multicellular (3) organisms are shown. Orthologues of structural genes relevant for mechanosensation or for development of polarity such as actin, tubulin, rare myosins, cadherins, espin, $\beta$ catenin and Wnt genes and several transcription factors are known in protists, Diploblasts (2) and various triploblasts and are thus ancestral to vertebrates. Note that the single celled ancestor of all multicellular animals, the choanoflagellates (1), has a single, actively beating kinocilium surrounded by microvilli that carry an actin core (A). In some diploblasts the central kinocilium is surrounded by an asymmetric assembly of microvilli of various diameters, potentially providing directional sensitivity

(B). Among deuterostomes, urochordates have various presumed mechanosensory cells that have a kinocilium with asymmetrically arranged microvilli. Vertebrates are unique in that a highly polarized, organ-pipe assembly of actin rich stereocilia is attached via tip links with each other and the asymmetrically placed kinocilium. Among protostomes, mollusks may have numerous, interconnected kinocilia on mechanosensory cells. Ecdysozoans have either mechanosensory cells with cilia or have a kinocilium that is stretched by the stimulus. Arrows indicate the direction of stimulation. Statocysts are known for many taxa of metazoans, but a lateral line system is restricted to few. Modified after (Arkett et al., 1988 , Budelmann, 1989, Burighel et al., 2003, Fritzsch et al., 2006b, Jorgensen, 1989, Steenkamp et al., 2006, Todi et al., 2005).

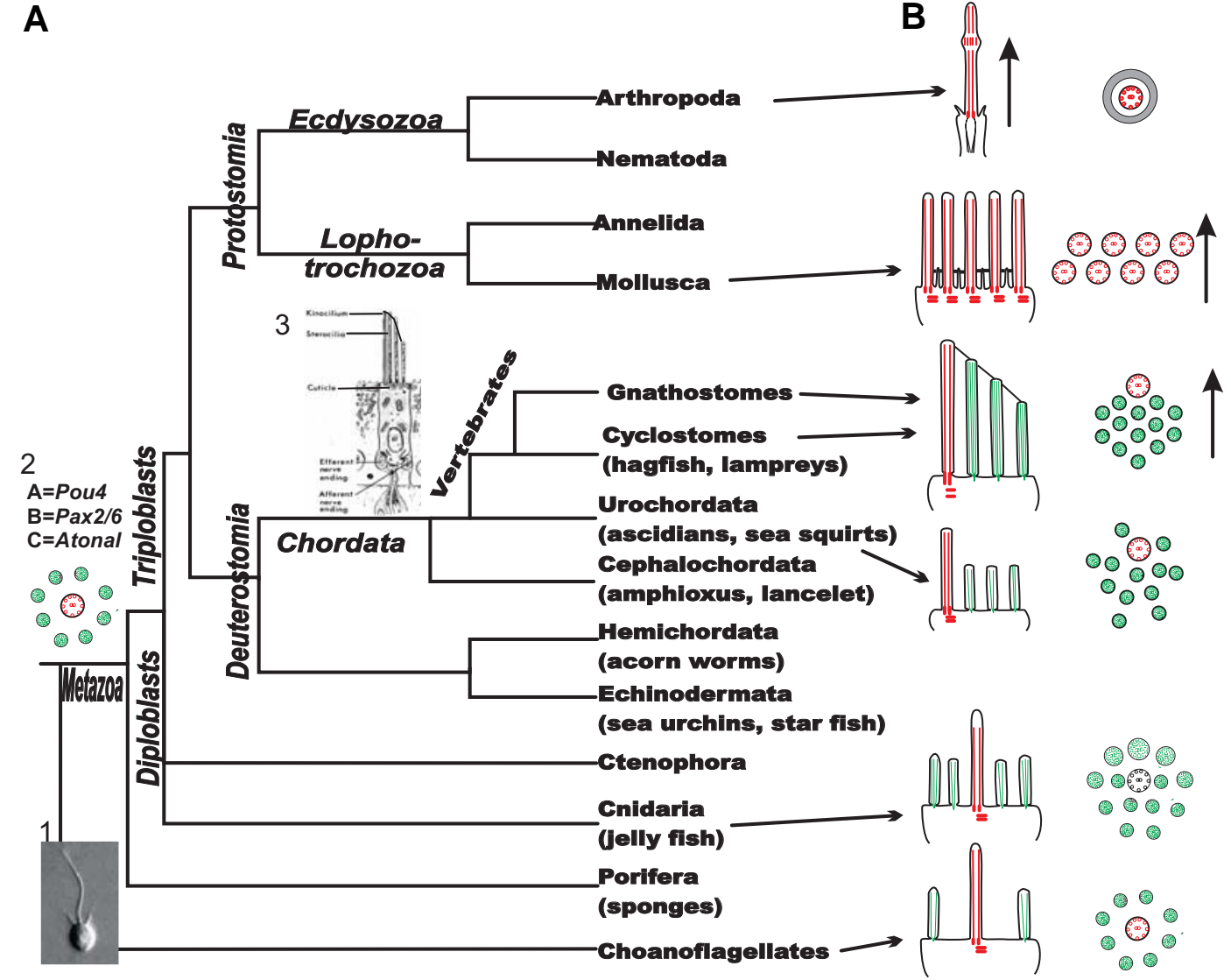


important function for cell survival through the molecular transition throughout evolution. Additional factors enabling the proneurosensory transformation and subsequent clonal expansion are Eya1, Six1and Gata3(Karis etal., 2001, Schlosser, 2006, Zou et al., 2006). Combined, these factors form a core for organ development and their absence is invariably associated with severe reduction if not entire loss of specific sensory development.

\section{Mechanosensory cells may represent an evolution- ary variation of a generalized cellular theme}

The above analysis suggests that mechanosensation as a cellular function could have evolved in single cell organisms, provided they have proper organization of cell protuberances to tether channels or to tether channels to a surrounding matrix. Indeed, the accepted single-cell origins of animals are protists that have a central kinocilium surrounded by microvilli that can be encased into a mineralized matrix, the choanoflagellates. The various apical specializations in metazoan cells that are suspected to play a role in mechanosensation can be organized into variations on a common theme (Fig. 3). In particular the deuterostome phylum resembles closely the organization of coelenterates and shows a variation of the common theme, a central kinocilium surrounded by microvilli. The hair cell of vertebrates always develops with a central kinocilium surrounded by microvilli and forms the asymmetric organization of the kinocilium with the staircase pattern of stereocilia under the influence of planar polarizing factors (Jones and Chen, 2007, Montcouquiol et al., 2006, Wang and Nathans, 2007). In contrast, most sensory systems of protostomia appear to be derived through reduction of stereocilia/microvilli at the expense of kinocilia. Arthropod scolopidial organs appear to be the most derived where stress along, rather across the kinocilium is the appropriate stimulation (Todi et al., 2005). Putative mechanosensors of less derived protostomia need to be investigated to understand the relationship of the apparently more derived features in this phylum with those found in Coelenterates and Deuterostomes.

Combined with the strong evidence of evolutionary ancestry of many cellular transcription factors and possibly certain components for the tethering of the mechanosensory transducer channel outlined above, it appears possible that hair cells of chordates represent a uniquely derived feature of an ancestral theme of mechanosensory cells and can be traced back to mechanosensory cells of coelenterates that also show some degree of asymmetric development (Fritzsch et al., 2006b). The grouping of these molecular and anatomical features make it increasingly less likely that mechanosensory cells arose through independent evolutionary events as previously suggested based on fewer data (Coffin et al., 2004). This grouping is also consistent with recent molecular data which suggests a close affinity between coelenterates and deuterostomes (Putnam et al., 2007).

\section{Evolution of mechanosensory organs: grouping single mechanosensory cells into arrays and organs for spe- cialized signal perception}

It is a dogma of evolutionary biology that single celled organisms evolved before the more complex multicellular organisms.
However, as far as sensory organ evolution is concerned, it appears to be conceptually difficult to accept the equivalence of mechanosensors represented either by single, distributed cells across the body or as a well organized sensory cell patch with a narrowly defined function of an epithelium in the vertebrate ear. However, recent years have shown that an ancestral global patterning of the body exists combined with a diffuse nerve net and singly distributed sensory cells (Burke et al., 2006, Lowe et al., 2003). Moreover, the basiepithelial nerve net or skin brain (Holland, 2003) maybe the ancestral condition in deuterostomes out of which the central nervous system evolved through concentration in a specific region (Fritzsch and Glover, 2006, Lowe et al., 2003)\}. It appears that such focal generation of the nervous system might be accomplished through altered patterns of gastrulation (Meinhardt, 2004). Most importantly, the molecular basis of this concentration process to form a central nervous system is molecularly distinct between protostomia and deuterostomia: the former require Fgf signaling, the latter do not (Bertrand et al., 2003, Delaune et al., 2005, Fritzsch and Glover, 2006). Comparable to this focal formation of a central nervous system is the local formation of all major sensory organs in chordates. Notably, as with the development of the central nervous system, development of the ear requires an epithelial transition that uses many of the same transcription factor families also used for central nervous system formation (Bailey et al., 2006, Fritzsch et al., 2006a, Litsiou et al., 2005). As much as the embryonic precursor of the brain is the neural plate, so is the embryonic precursor of the ear the otic placode. In contrast, the evolutionary precursor of the brain is the diffuse nerve net whereas the evolutionary precursors of the ear might be single, diffusely distributed mechanosensory cells.

If we accept this interpretation, it then follows that evolution of placodes must be interpreted as an embryonic adaptation to ensure development of mechanosensors only in distinct places as compared to ubiquitous distribution over the entire skin. Indeed, in many chordates and also in amphioxus there is distribution of single sensory cells in the skin, suggesting that the capacity of the skin to generate diffusely distributed sensory cells is not fully suppressed in these species or may be the only sensory arrangement (Fritzsch et al., 2006b, Holland, 2005). Moreover, it appears that such concentration of sensory precursors evolved independently several times in metazoans but might use only a limited set of conserved transcription factors to do so thus leading to a false impression of homology that is largely based on the common and ancestral, cellular development regulating transcription factors. In the following we want to discuss one specific transcription factor that is involved in ear development and has been thoroughly analyzed across several relevant taxa.

In vertebrates, Pax8is among the earliest genes unequivocally expressed in the developing otic placode of fish and mice (Nornes et al., 1990, Pfeffer et al., 1998) and appears to be largely coexpressed with Pax2in the mouse ear (Bouchard etal., 2002, Zou et al., 2006). Several papers have at least partially characterized the effects of Pax2null in the mouse ear (Burton etal., 2004, Favor et al., 1996, Torres et al., 1996, Zou et al., 2006) and show that Pax2function is essential for development of the cochlea in mice and human. Although the cochlea is a mammalian novelty (Fritzsch et al., 2006b, Fritzsch et al., 2006c), there is expression of Pax2 in the ear of bony fish that have no cochlea (Pfeffer et al., 1998, 
Riley, 2003). Pax2 expression in mammals is thus unlikely to reflect the ancestral function of Pax 2 in vertebrate ear development.

In addition, the functional analysis of $d$-Pax2, the fly Pax2/5/8 orthologue, has shown the involvement of this gene in the bristle selection process and, most importantly, in the differentiation of the shaft and sheath cells (Kavaler et al., 1999). However, whether $d$-Pax2plays any role in chordotonal organ formation, in particular in the Johnston hearing organ development of flies, is unknown. At a cellular level, several genes suggest homology between chordotonal organs of flies and hair cells in mammals, but much less evidence exists for surface mechanoreceptors related to bristles (Caldwell and Eberl, 2002, Fritzsch and Beisel, 2004, Todi et al., 2005). Vertebrate Pax8 is highly expressed in both neurosensory (including sensory neurons) and non-sensory areas, resembling thereby the expression of $d$-Pax 2 in the fly mechanosensory bristle development. Pax2/5/8 is also associated with the statocyst of mollusks, suggesting some more specific association with mechanosensation in some Protostomes (O'Brien and Degnan, 2003). The issues around Pax $2 / 5 / 8$ are equally unclear in Deuterostomes. Problematic for any attempt to use Pax2to establish organ homology is the widespread expression of Pax2 in the tube feet of sea urchins (Czerny et al., 1997) which have no know mechanosensory organ in those structures (Burke et al., 2006) and the absence of Pax2 expression in the ectoderm of amphioxus (Kozmik et al., 1999) which are known to have single sensory cells in part suspected to be mechanosensitive (Holland, 2005). Combined with the apparent absence of function of $d$-Pax2in fly chordotonal organ development this suggests that the association of the Pax2transcription factor with the formation of mechanosensory organs is more variable then the association of Pax6 with photoreceptors and may suggest that Pax2/5/8may play no role in the development of single mechanosensory cells. Whether the association of Pax $2 / 8$ with vertebrate ear formation stems from chance or necessity remains to be analyzed once the development of mechanosensory organs in additional taxa has been elucidated. It remains therefore unclear at which time in the evolution of the vertebrate otic placode Pax $2 / 8$ became associated, but $P a \times 2 / 8$ is now an integrated aspect of molecular development of the vertebrate ear.

Beyond this unclear situation of $\mathrm{Pax} 2 / 8$, placode evolution needs to be interpreted in the context of global pattern formation in the course of evolution of the dorsal central nervous system of chordates. Apparently, Deuterostomes such as amphioxus and sea squirts have the same central patterning process, but only sea squirts have Pax $2 / 5 / 8$ expression outside the central nervous system in structures interpreted by some as being possible homologues of the vertebrate ear (Kozmik et al., 1999, Krelova et al., 2002, Mazet et al., 2005, Mazet and Shimeld, 2005, Schlosser, 2006, Wada et al., 1998). Such interpretations seem to be supported by the existence of cells in those areas that have apical specializations consistent with their possible function as mechanosensors (Burighel et al., 2003) but others argue against this (Holland, 2005). We are just beginning to understand how various factors interact with each other to generate the otic placode out of a much larger protoplacode (Bailey et al., 2006, Litsiou et al., 2005, Schlosser, 2006, Torres and Giraldez, 1998) through conversion of ectodermal cells to a new fate, formation of neurosensory and non-neurosensory otic cells (Fritzsch et al., 2006a). Clearly, resolution of this discussion requires the study of many more factors involved in global patterning ( $W n t, B m p, S h h$ ) and genes that are expressed in the ear (Sox2, Gata3, Neurog1, Atoh1, Prox1, Is/1, Foxg1, Six1, Eya1) in more Deuterostomes (Fritzsch et al., 2006a, Ohyama et al., 2006, Schlosser, 2006) before a conclusion can be reached. It is entirely possible that the obvious, small set of similarities in mechanosensory organ specific genes across phyla might have come about by an evolutionary independent transformation of genes involved in mechanosensory cell formation and organization into a localized group of cells driven by the global patterning process. The likely ancestral set of genes necessary for mechanosensory cell development will make it difficult to solve this problem. It will therefore be critical to analyze the otocyst/statocyst development in such distant species as squids and cuboidal medusas to appreciate similarities in the molecular basis of organ development. Combined with a better understanding of molecular pathways, we will eventually be able to distinguish between chance and necessity of molecules in organ development.

In summary, the most likely evolutionary scenario for statocysts and chordate otocyst evolution is the transformation of widely distributed, ancestral single mechanosensory cells into mechanosensory organs (Fritzsch etal., 2006b, Jorgensen, 1989). Much like the discussion in the evolution of the visual system (many structurally distinct eyes consist of photosensitive modules that have convergently been organized into organs) can be resolved with this approach (Gehring, 2005), the apparent molecular similarities in otherwise rather different organs can be viewed as multiple, convergent evolution of various statocysts, including the vertebrate ear, out of diffusely distributed single mechanosensory cells. Indeed, in certain sea stars the tube feet near the tip of an arm can differentiate into eye-like organs, showing within an organism how diffuse gene expression of Pax6 can be reorganized in certain areas only to govern photoreceptor development.

Older ideas discussed the lateral line system as a precursor of the ear. However, comparisons of the prevalence of lateral line and statocysts among metazoans suggest that every aquatic free swimming animal has a statocyst but only a small number have evolved lateral line-like organs (Bleckmann et al., 1991, Jorgensen, 1989). Evolving both hydrodynamic and gravistatic organs out of an ancestral single mechanosensory cell indicates that this controversial discussion might essentially be obsolete as both might have evolved as a consequence of the global patterning change that led to the formation of a central nervous system and otic placodes in chordates (Fritzsch and Glover, 2006, Lowe et al., 2003, Meinhardt, 2004).

\section{Ear morphogenesis requires conserved genes for branching morphogenesis}

Many, if not all, of the transcription factors used in ear development existed in chordate ancestors and apparently evolved as a nested set of genes for various aspects of branching morphogenesis, including intrusion or extrusion of lungs, glands, tracheas and limbs. Ear evolution has apparently tapped into this readily available resource of genes as the basic module to govern invagination and formation of canals (Fig. 4). However, while branching morphogenesis is typically a process of mesenchym/ 
ectoderm interaction, factors typically expressed in the mesoderm are expressed in the sensory epithelia in the ear. For example, in lung and lacrimal gland development, Fgf10 is expressed in the mesoderm near the leading edge of the ectodermal invagination (Govindarajan et al., 2000, Makarenkova et al., 2000)). However, in the ear the expression of Fgf10moves rapidly into the ectoderm where it becomes focally expressed in the developing sensory organs (Pauley et al., 2003, Wright et al., 2003).

While involvement of the Fgf/branchless/breathless signaling pathway is not known to play a role in fly auditory organ development, there is a striking similarity in overall conservation of genes found to interact with each other in vertebrate ear and fly trachea development (Fig. 4). This impressive conservation of possibly functional interactions of genes, albeit in non-homologous organs, suggests a degree of molecular network stability that requires transposition of entire functional modules as components of developing systems. It is likely that the context of other genes expressed in the developing fly trachea and vertebrate ear will determine the outcome in terms of expression profiles of downstream genes. In analogy to the idea proposed for eye evolution, namely that only the top transcription regulator and the bottom functional genes may be conserved (Gehring, 2005), this example suggests that entire cascades of genes may be intercalated or added as functional modules to an existing program for overall similar and yet clearly distinct functions. Thus, branching morphogenesis in fly trachea and vertebrate ear have only very rudimentary developmental aspects in common, growth through proliferation and splitting of the growth plate into two parts that result in different outcomes. Most important for our consideration here is that the developmental program of otic vesicle of early chordates had already the potential to tap into an existing module that can drive specific aspects of morphogenesis. Effective use of this resource required the regulation of the expression of the entire module in the ear and modification of the signals to achieve new goals; namely, the formation of two or three canals instead of one, as in hagfish. While the outgroup comparison with fly trachea development strongly supports this model, demonstrating that hagfish have the same module but do not express it in the developing ear would provide even stronger support for this model. Limited evidence does support this idea for certain ear morphogenesis genes (Fritzsch et al., 2001, Hammond et al., 2002, Hammond and Whitfield, 2006).

\section{Evolution of the vertebrate ear through segregation of epithelial patches into a multifunctional organ}

Outgroup comparison suggests that the original vertebrate ear was likely a gravistatic organ not unlike the many statocysts found in metazoan animals. Evolution of an angular acceleration system mediated by semicircular canals appears to have occurred only among crustaceans, cephalopods and vertebrates (Budelmann,

\section{Drosophila melanogaster}

Fig. 4. Comparison of the genes involved in trachea formation in flies with inner ear development in mice. Icons of the same shape and color represent homologous genes in Drosophila m. and Mus m. Known interactions between genes are demonstrated by the black arrows. Several homologous genes have been identified in these developmental pathways, but their interactions have not yet been fully described in either species. Putative sequence of activation is from the top with the fly and louse Fgf/Fgfr system providing the integration between patterning events outside the trachea/ear and intracellular signaling that leads to morphogenesis The striking resemblance of these genes as a complex interacting module supports a model in which not only are individual genes conserved across phyla, but the entire signaling network is conserved and utilized in the development of diverse structures, governing various aspects of branching morphogenesis. We recently tested the predictive value of this model and reported on the effect of Foxg1, the orthologue of Slp1+2 (Lee and Frasch, 2004, Mondal et al., 2007), in mouse ear development (Pauley et al., 2006). More of the listed genes should be tested for such conserved function to assess how much of the entire developmental mod-

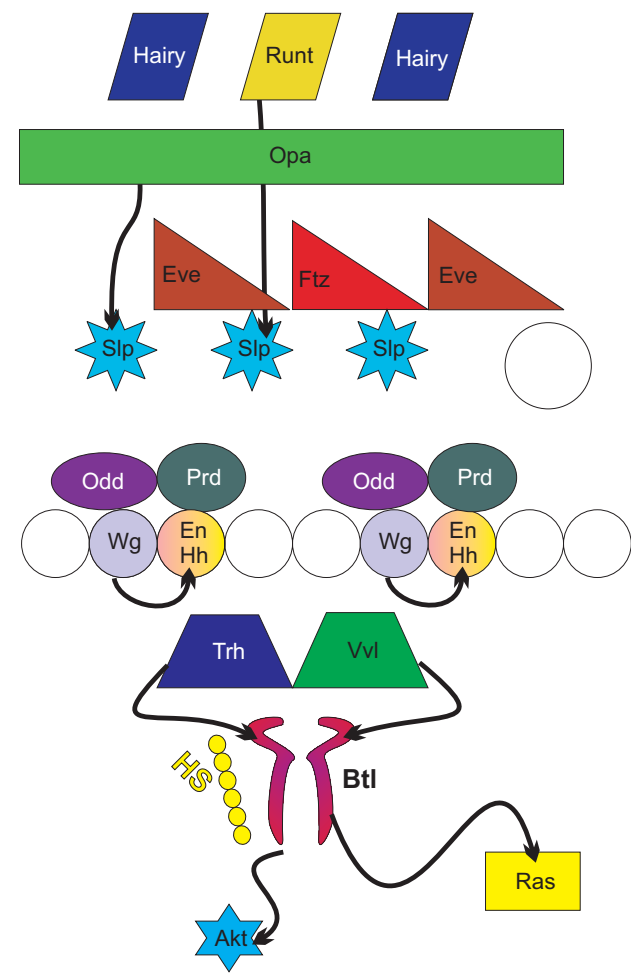

Survival, Growth and Differentiation

\section{Mus musculus}

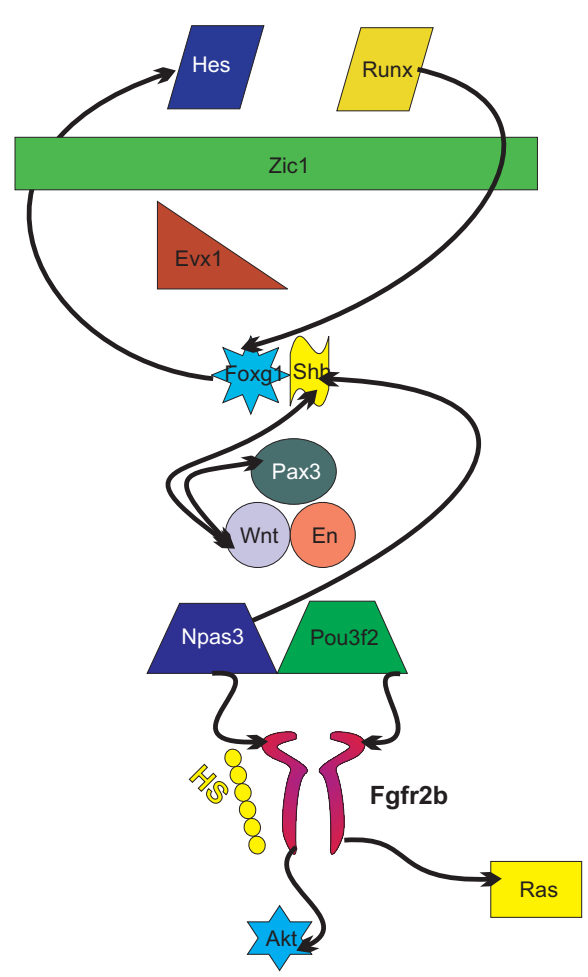

Survival, Growth and Differentiation ule is invariable and thus needs to be inherited as an entire cascade of gene interactions with modifications to suit the need of the specific tissue in question. Modified after (Swantek and Gergen, 2004). Gene names follow the nomenclature as published in PubMed. 
1987) and can thus be regarded as a derived feature of statocysts. Viewed from this perspective, one of the major driving forces for ear evolution would be the possibility for segregation and morphological specialization of distinct epithelia dedicated to detect specific sensory stimuli. This can be achieved through the association with unique morphologies that filter specific components of the stimuli (semicircular canals and otoconia, for example). In vertebrates, this leads to the evolution of up to nine distinct sensory organs [three semicircular canal cristae, utricle, saccule, lagena, cochlea/basilar papilla, neglected papilla, amphibian papilla; gymnophionans (Fritzsch and Wake, 1988)] out of a single common macula and two canal cristae [hagfish (Lewis et al., 1985)].

Segregation of sensory patches (Fig. 5) is related to increased numbers of hair cells, but the stereotyped segregation of sensory organs combined with the various ways of adding hair cells in vertebrates [continuous addition over a long time as in bony fish (Millimaki et al., 2007, Riley, 2003), lampreys (Hammond and Whitfield, 2006)), sharks (O'Neill et al., 2006)) or amphibians(Fritzsch et al., 1988) or short burst of formation of all hair cells as in mammals (Matei et al., 2005, Ruben, 1967)] suggests that the two processes are at a certain level independent. What drives segregation of sensory patches is still unclear (Fritzsch et al., 2002) despite suggestions of possible involvement of certain molecules (Daudet and Lewis, 2005). More specifically, one has to distinguish genes necessary to conduct the separation from genes that actually initiate such segregation. While the delta/notch system clearly plays a role in this process (Daudet and Lewis, 2005) it may require interaction with other factors for the segregation, comparable to the Hes 7 activity in somite formation (Dequeant et al., 2006). Outgroup comparison shows the existence of the delta/notch pathway already in flies and it therefore likely exists in hagfish and lampreys which do have a common macula that does not segregate into patches. In essence, one or more genes are needed that play this role as much as the Sox2/Atoh1genes play this role for hair cell formation [which also is reinforced by the delta/notch system (Fritzsch et al., 2006a, Kelley, 2006b)].

One of the genes involved in segregation of sensory epithelia is Otx1. In null mutants of that gene there is incomplete segregation of utricle and saccule across the utriculo-saccular foramen and the horizontal crista may not segregate completely from other sensory patches (Fritzsch etal., 2001, Morsli etal., 1999). Indeed, lack of morphogenetic segregation in lamprey was recently attributed to the absence of Otx1 (Hammond and Whitfield, 2006) as previously suggested (Fritzsch et al., 2001). Data on Otx1 mutants as well as others (see below) suggest that segregation and morphogenesis are linked, but the molecular basis of this link is not completely clear (Chang et al., 2004a, Chang et al., 2004b, Fritzsch etal., 2006b, Fritzsch and Wake, 1988). More genes that function like Otxgenes are needed to fully understand what drives sensory epithelial segregation; in particular the segregation of canal cristae from gravistatic organs.

Segregation allows sensory epithelia to develop unique molecular properties that initiate formation of, for example, acellular covering structures that permit acquisition of specific stimuli (canal crista have cupulae, gravistatic organs have otoconia/ otoliths and auditory organs have tectorial membranes, except for bony fish) and have specific associated morphologies to direct stimuli to the endorgans (canal cristae are associated with semicircular canals for angular acceleration perception; gravistatic organs are in recesses that are oriented in different directions for horizontal and vertical stimulus perception; auditory organs are associated with specific sound conducting pathways that extend from the sound entry point (e.g., stapes footplate) to the sound exit point (e.g., round window).

It is obvious that sensory epithelia diversification goes hand in hand with histological and morphological alterations of the ear. In principle there are two ways through which coordinated morphogenesis and histogenesis could be achieved: either a set of genes is driving morphogenesis from the sensory epithelia primordia, or common upstream regulators exist that simultaneously regulate both histogenesis of the sensory epithelia and morphogenesis of surrounding accessory structure. Little evidence exists at the moment for the second way of regulating ear development and normal ear morphogenesis in Atoh 1 null mice (which lacks differentiated hair cells) suggests that it is not hair cells but sensory epithelia precursors that regulate ear morphogenesis (Fritzsch et al., 2005a). In line with this assumption are the morphogenetic defects reported for Sox2 hypomorphic mice, mice that do not even develop recognizable prosensory patches (Kiernan et al., 2005).

Consistent with this assumption is also that mutants in several genes expressed in prosensory patches prior to hair cell formation such as Foxg1, Fgf10 and Jag1 null mice lack or have reduced prosensory canal cristae formation and all have canal formation deficits (Brooker et al., 2006, Kiernan et al., 2006, Pauley et al., 2003, 2006). In contrast, when prosensory epithelial formation is disrupted before prosensory patches even form as in Neurog1 null mice (Matei et al., 2005) or Tbx1 mutants (Raft et al., 2004, $\mathrm{Xu}$ et al., 2007), there is altered morphogenesis. Therefore, the sensory epithelia primordia / supporting cells, but not the hair cells, are critical for canal development (Matei et al., 2005, Pauley et al., 2003, Wright and Mansour, 2003). Below we will explore in some detail how Fgf10 might achieve this effect.

Many crucial functions of FGFs are conserved across phyla. In contrast to vertebrates where FGFs play a crucial role in neural plate formation (Bertrand et al., 2003), there is no evidence for FGF signaling in this context in fly development, suggesting that the FGF function in neuronal formation is a new acquisition of vertebrate Fgfs (Fritzsch and Glover, 2006). In Drosophila, these genes regulate cell migration and branching patterns in trachea and limb bud formation (Sutherland et al., 1996) whereas EGFr signaling is performing signals associated with FGF signaling in vertebrates, most importantly in chordotonal organ development (Eberl and Boekhof-Falk, this volume). This role in branching morphogenesis is conserved in vertebrates and is most readily apparent in the Fgf10 null mice which do not form lungs, glands or limbs. The FGFs known to be involved in mammalian inner ear development are Fgf3, 8, 10. Others of the over 20 FGFs still need to be investigated (Zhang etal., 2006). As with the CNS, FGFs are not present in the insect mechanosensory system development, but play a major role in the development of the vertebrate inner ear. Specifically, Fgf10mutants show significant defects in canal outgrowth and development, particularly in the posterior canal system (Pauley etal., 2003). FGF10 has the highest affinity for the B isoform of FGFR2 (Zhang et al., 2006); and Fgfr2b null mice show agenesis of the ear through arrest of morphogenesis at the 
A

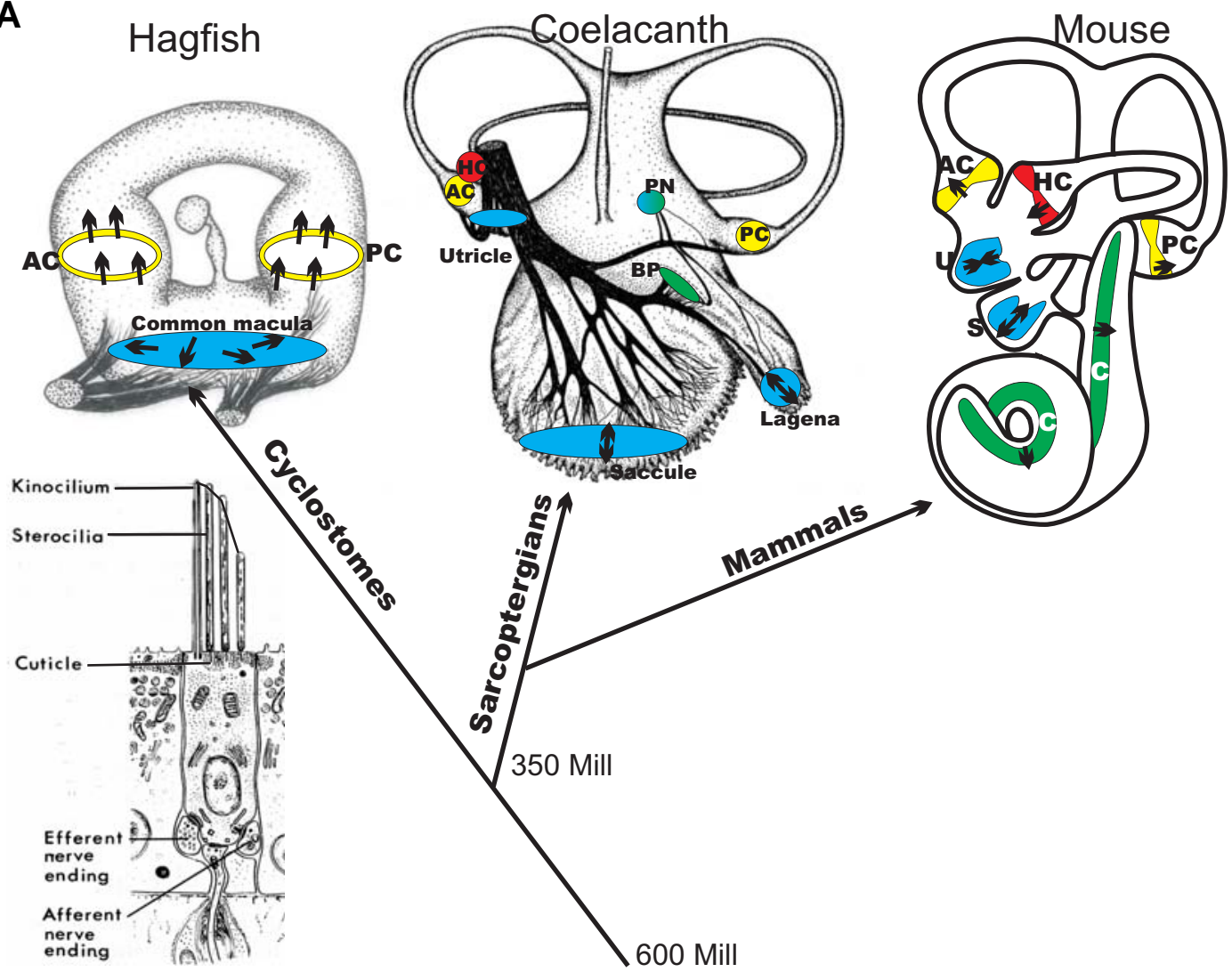

B

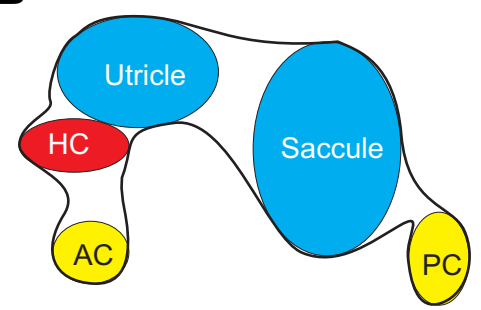

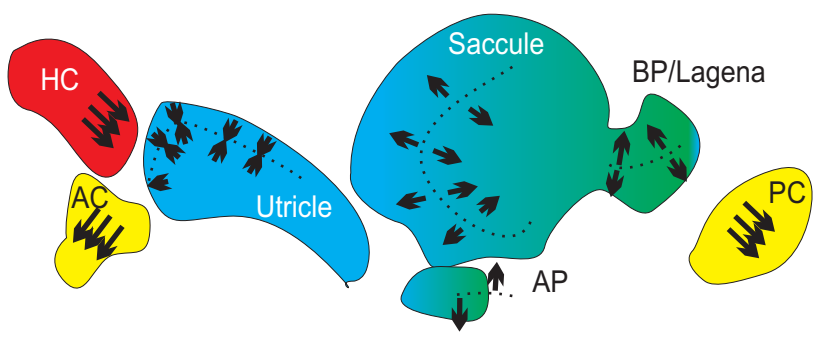

Fig. 5. Crucial steps in vertebrate ear evolution $(A)$ and development $(\mathrm{B})$ are depicted. It is assumed that the vertebrate hair cells with afferents and efferents co-evolved with the ear (insert) some 600 million years ago. Note that the ears of the three depicted vertebrate species differ in the number of canal cristae (hagfish has two, coelacanth [Latimeria] and mouse have three), number of vestibular organs (hagfish has one [common macula], coelacanth has three [utricle, U; saccule, S; lagena, L] and mouse has two [utricle, U; saccule, S]) and number of organs near perilymphatic ducts (none in hagfish, two [basilar papilla, BP; papilla neglecta, PN] in coelacanth and one lorgan of Corti of the cochlea, C] in mouse). Major morphological evolutionary changes are the addition of a horizontal canal in gnathostomes and the transformation of the utricle into several recesses containing the saccule, lagena and cochlea. It is suggested that the evolution of up to nine sensory organs of the vertebrate ear (A) comes about through ontogenetic segregation of a single primordium into multiple sensory patches (B). After segregation, each sensory patch differentiates along a unique trajectory to form adult epithelia that perceive discrete aspects of the mechanical stimulation that reaches the ear (A). Development (B) therefore recapitulates the evolutionary segregation and differentiation of various epithelia from a common precursor. Integrated into this differentiation is the organization of different polarities of hair cells (arrows in B) that can be opposing (utricle, saccule, lagena) or one polarity (canal cristae). Note that the polarity of hair cells in the cristae is similar in anterior and posterior crista (away from the gravistatic organs), whereas the horizontal crista is polarized toward the gravistatic organs. How the ancestral molecular pathway to set up cellular polarity in the various sensory epithelia has been modified remains unclear. Modified after (Fritzsch and Beisel, 2004, Fritzsch et al., 2002).

otic vesicle stage (Pirvola et al., 2000). Other members of the Fgf family are critical for ear development. Fgf3/Fgf\&knockdown zebra fish do not develop otic vesicles (Maroon et al., 2002, Riley, 2003) and the $F g f 3 / F g f 8$ combination is essential for placode formation in mice and chicken (Ladher et al., 2005). Similarly, Fgf3/Fgf10 double null mice show only limited formation of occasional micro vesicles (Alvarez et al., 2003, Wright and Mansour, 2003). An ear does form in Fgf3mutant mice, but the size reduction of the ear is apparently different in the two Fgf3null lines, ranging from vesiclelike (Mansour, 1994) to apparently normal (Alvarez et al., 2003).

Canal morphogenesis can be disrupted by a number of factors (Chang et al., 2004a, Pauley et al., 2006). FGF10 is known to interact with BMP4, which appears in the early development of the Drosophilamechanosensors and is part of the upstream regulation of cell fate determination. In the mammalian inner ear, Fgf10 and Bmp4are both expressed in the presumptive sensory epithelia and they interact during canal morphogenesis (Chang et al., 2004b). Further, Bmp4 has been shown to reduce the size of prosensory patches, while Noggin, a BMP-inhibitor, increases the prosensory domain, thereby increasing the area of Fgf10expression (Pujades et al., 2006).

We propose that $F g f 10$, consistent with its conserved function in branching morphogenesis (Fig. 4), acts as a central node in canal morphogenesis. We propose that prosensory crista size and the number of sensory epithelial precursor cells, determined by the molecular networks outlined above, determines the amount of Fgf10 expression, which in turn regulates canal growth in interaction with other genes. Recently, genes known to affect ear growth 
and morphogenesis have been found to bind the promoter region of the Fgf10 gene. Among those genes are Gata3, a gene that affects ear morphogenesis (Karis et al., 2001) and several genes known to affect canal formation such as HoxA1, HoxB1, DIx and Nkx genes (Chang et al., 2004a, Ohuchi et al., 2005). Unfortunately, many of these genes have not been studied for their role in histogenesis or for expression of the key Fgfs or Bmps in the sensory epithelia. Further support for the idea that Fgf10 is a central node of canal morphogenesis is the absence of all canal formation in Fgf10 null mice (Ohuchi et al., 2005, Pauley et al., 2003). Another category of genes appears to act downstream of Fgf10and determines the fusion of the canal plate. One such gene is Netrinwhich appears to influence overall canal radius (Salminen et al., 2000). EphB2and Nor-1 are responsible for the diameter of the canals (Cowan et al., 2000, Ponnio et al., 2002). Further, the final diameter of the canals also depends on endolymph production and is enlarged in the Foxi1 null mice due to endolymphatic hydrops (Hulander et al., 2003). Importantly, loss of crista formation in Jag1 or Foxg1 null mice results in partial loss of canal formation (Brooker et al., 2006, Kiernan et al., 2006, Pauley et al., 2006). In the Fgf10null, there is some 'rescue' of the anterior canal. This is likely mediated by Fgf3, which is expressed in the anterior portion of the developing otocyst (Wright et al., 2003). This Fgf3 expression may be too far away from the posterior crista to rescue its crista and canal development.

Our data show that Foxg1 is at least one additional factor that cooperates with Fgf10 to determine size of sensory epithelia and thereby the signal needed to interact with BMPs for proper canal growth (Chang et al., 2004a) likely through interaction with Smad signaling (Massague et al., 2005). Combining Foxg1with Jag1null mice should help to further clarify the complex interactions emerging in the NOTCH/HES/bHLH signaling system in the ear (Brooker et al., 2006, Fritzsch et al., 2006a, Matei et al., 2005).

In addition to the FGFs and BMPs required for all canal development, novel genes have been recruited for the development of the horizontal crista. The horizontal canal system has some capacity to form independently of a horizontal crista, as demonstrated by the Foxg1null mouse in which the horizontal canal forms but the horizontal canal crista is lacking (Pauley et al., 2006). Another gene that is critical to the horizontal canal system is the Otx 1 gene. Otx 1 null mice completely lack a horizontal canal, yet

Fig. 6. The transformation of the ear, sensory neurons and brainstem from a non-auditory, primitive condition, into the derived condition, enabling a tetrapod vertebrate to hear, is shown. The primitive ear has vestibular sensory epithelia (VE) that are connected with vestibular sensory neurons (VN) to the vestibular nuclei of the brainstem (VeNu). Additional sensory systems in primary aquatic vertebrates are the electroreceptive ampullary organs (AO) and the mechanosensory neuromasts of the lateral line (NEU). These organs are connected via specific sets of sensory neurons (ELL, $L L)$ to specific brainstem nuclei (ELLNu, LLNu). Derived land vertebrates have lost these senses and have a sound pressure receiving sense, called hearing. This sense is characterized by the auditory epithelium (AE) that sits at or near a sound conducting perilymphatic system (PLS) and is covered with a tectorial membrane (TM). Auditory neurons (AN) conduct the information from the auditory epithelium to the auditory nuclei ( $\mathrm{AuNu}$ ) of the brainstem. This basic organization may have evolved in the aquatic ancestor of terrestrial vertebrates, but was modified in amphibians through the addition of the amphibian papilla and in amniotes through the formation of the cochlea. Modified after (Fritzsch and Neary, 1998). the horizontal canal crista forms and is properly innervated (Cantos et al., 2000, Fritzsch et al., 2001). These observations support the idea that the evolution of the horizontal canal system occurred in two phases: i) the formation of a separate sensory epithelia, likely by additional growth and splitting of an existing epithelial patch, mediated in part by Foxg1; and ii) the formation of a horizontal canal through the recruitment of Otx1. Combined these data point to the critical steps for canal morphogenesis in general and provide some insight into the evolution of the horizontal canal system. The expression of most of those genes prior to exit of hair cells from the cell cycle suggests that it is the size of the neurosensory precursor population and the expression of crucial genes such as Fgf10and $B m p 4$ that ties neurosensory histogenesis into ear morphogenesis in the canal system. In contrast to the canal development, the cochlea grows through convergent extension (Lee etal., 2006) but this process can also be compromised by eliminating some of the genes known to affect canal and gravistatic receptor morphogenesis (Otx, Neurog1, Foxg1, Sox2, Delta, Notch).

\section{Evolution of auditory receptors: from a simple sensory patch to complex morphogenesis}

As outlined above, diversification of sensory function of the ear follows the well established principle of molecular evolution: duplicate, mutate and select the new gene for a new function using changes in the cis-regulatory elements (Sodergren et al., 2006) while keeping the old for the ancestral function. There is uniform
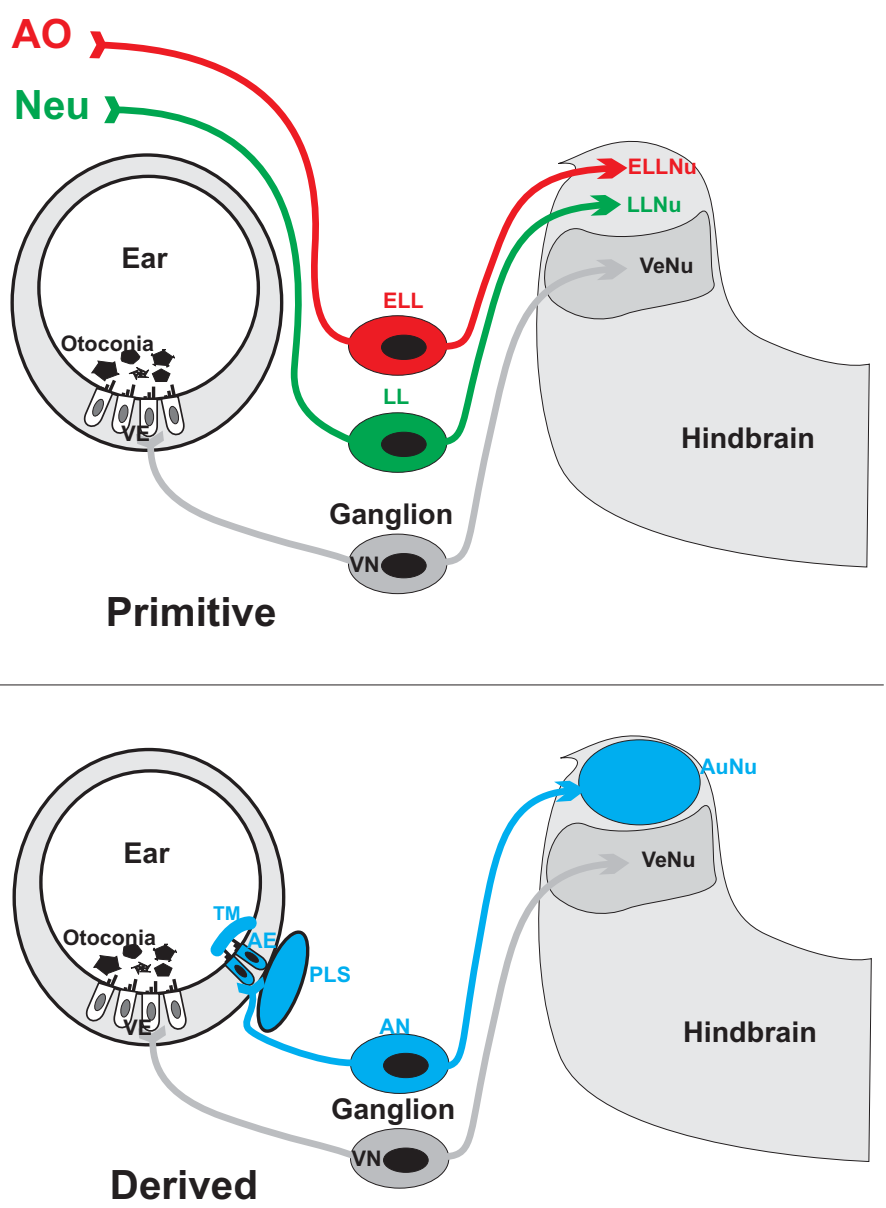
agreement that ear evolution started with a gravistatic and angular acceleration sensing vestibular ear (Fig. 6). As outlined above, formation of new functions in the vestibular system requires genes for formation of new sensory epithelia to associate with novel aspects of morphogenesis that may use different genes than those used for anterior and posterior canal morphogenesis. It appears that one of these events of sensory epithelia splitting may have already generated a novel epithelium in aquatic tetrapod ancestors (Fritzsch, 1992, Fritzsch, 2003). However, evolving this new sensory epithelium into a novel type of receptor, an auditory receptor, requires sophisticated reorganization of the periotic space to allow the formation of perilymphatic fluid filled space from the sound input to the sound output part of the ear, the oval and round window. It is conceivable, but not known at the molecular level that forming the cochlea sensory epithelia will help organize the perilymphatic space surrounding the cochlea. It is important to note that such perilymphatic specializations can evolve no matter which sensory epithelium is converted into an auditory system (Fritzsch, 1999), suggesting that the relevant genes are an ancestral module of ear development. Future research should focus on this important aspect of perilymphatic reorganization without which sound conduction from the tympanic membrane to the round window would be impossible. Unfortunately almost nothing is known on this subject as it has not been investigated in mutants with disrupted cochlea morphogenesis.

In addition to directing sound to this novel sensory epithelium, a novel set of neurons dedicated to conduct sound related information to the brain needed to evolve with molecular mechanisms to ensure a discrete connection to the sound processing sensory epithelium and a set of central neurons dedicated to receive this information rather then vestibular stimuli. In mammals we know some of those novel features. For example, a second neurotrophin, Ntf3 (NT-3) is expressed in the basal turn of the cochlea and avoids rerouting of vestibular fibers which can be experimentally induced in transgenic animals that express the neurotrophin Bdnfunder control of the Ntf3promoter (Tessarollo et al., 2004). In addition, mammals express the transcription factor Gata3 in the spiral ganglion neurons and this factor may play a role in pathfinding (Karis et al., 2001). Clearly, more needs to be known on this subject before we can begin to appreciate the steps taken to molecularly ensure proper routing of spiral ganglion cells and can use this information to enhance fiber growth during regeneration (Martinez-Monedero et al., 2006).

Molecular understanding of cochlear nucleus development is moving ahead. In chicken and mice we now understand the rhombomeric orgin of cochlear nuclei (Cramer et al., 2000, Farago etal., 2006, Fritzsch etal., 2006c) and also know that most neurons depend on the very same transcription factor that is essential for hair cell differentiation, Atoh1 (Fritzsch et al., 2006c, Wang et al., 2005). These initial steps are certainly too crude to define the many neurons thus far recognized in the cochlear nuclei of vertebrates, but it is remarkable that the rhombomeric origin fits reasonably well to the recognized subdivisions of the cochlear nuclei in mice. Rhombomere 2 could generate the anterior subdivision of anterior ventral cochlear nucleus, rhombomere 3 could generate the posterior subdivision of the cochlear nucleus, rhombomere 4 could generate the neurons of the inferior division of the posterior ventral cochlear nucleus, rhombomere 5 could generate the octopus cells of the dorsal cochlear nucleus and rhombomere 6 could generate the remaining part of the dorsal cochlear nucleus (Ehret and Romand, 1997). More work using the approach of rhombomere specific expression of Cre (Farago et al., 2006) combined with a floxed Atoh1 or Neurod1 could be used to selectively eliminate cochlear nucleus development in a rhombomere specific fashion and the effect on central neurons could be analyzed.

\section{Summary and outlook}

Within recent years it has become clear that evolution of senses is predominantly evolution at the receptor level while tapping into neuronal plasticity for information processing. For example, evolution of trichromatic vision has been reconstructed in mice through expression of a long wavelength opsin. Surprisingly, mice can process this new information through the apparently built in plasticity in their neuronal information processing system (Jacobs et al., 2007). It has also been shown that Wnt induced formation of 'vestibular' hair cells in the chicken cochlea results in altered innervation with the possibility that these cells are connected to vestibular rather than auditory nuclei (Stevens et al., 2003). It thus appears that we need to interpret evolution of mechanosensors and evolution of auditory organs out of vestibular organs primarily at the level of the receptor changes. It appears likely that the candidate receptor molecules evolved with multicellular organisms (Beisel et al., 2007). When and how they were selected for the hair cells remains to be shown. Other issues such as formation of new sensory epithelia and segregated projections of innervating afferents to a distinct information processing part of the brain may be instantly sorted owing to the brain's capacity to plastically respond to altered sensory input. Of course, selection will ultimately drive complete segregation through picking developmental modules via changes in their promoter region. Such changes will accommodate more refined information processing through the evolution of accessory structures and the evolution of uniquely dedicated information processing pathways. While gathering information about such structures is informative in its own right, it is the receptor that primarily drives sensory evolution. In this context, it is important to reiterate that more work is needed to resolve open issues on the molecular basis of mechanoreceptor cell evolution to reconcile the apparent histological differences with the apparent conservation of certain cell fate determining genes.

\section{Acknowledgements}

This work was supported by a grant from NIH (RO1 DC005590; BF; $D C 005009 ; K B$ ) and NASA (NAG 2-1611; BF, KB), COBRE (1P20RR018788-01; KB, BF; GS) and LB692 (BF, KB). This investigation was conducted in a facility constructed with support from Research Facilities Improvement Program Grant Number 1 C06 RR17417-01 from the National Center for Research Resources, National Institutes of Health. We acknowledge the use of the confocal microscope facility of the NCCB, supported by EPSCOR EPS-0346476 (CFD 47.076).

\section{References}

ALONSO, C.R. and WILKINS, A.S. (2005). The molecular elements that underlie developmental evolution. Nat Rev Genet 6: 709-15.

ALVAREZ, Y., ALONSO, M.T., VENDRELL, V., ZELARAYAN, L.C., CHAMERO, P., THEIL, T., BOSL, M.R., KATO, S., MACONOCHIE, M., RIETHMACHER, D. 
et al. (2003). Requirements for FGF3 and FGF10 during inner ear formation. Development 130: 6329-38.

ARENDT, D., TESSMAR-RAIBLE, K., SNYMAN, H., DORRESTEIJN, A.W. and WITTBRODT, J. (2004). Ciliary photoreceptors with a vertebrate-type opsin in an invertebrate brain. Science 306: 869-71.

ARKETT, S.A., MACKIE, G.O. and MEECH, R.W. (1988). Hair cell mechanoreception in a jellyfish Aglantha digitale. Journal of Experimental Biology 135: 329342.

BAILEY, A.P., BHATTACHARYYA, S., BRONNER-FRASER, M. and STREIT, A. (2006). Lens specification is the ground state of all sensory placodes, from which FGF promotes olfactory identity. Dev Cel/11: 505-17.

BEISEL, K.W., HE, D., HALLWORTH, R. and FRITZSCH, B. (2007). Genetics of Mechanoreceptor Evolution and Development.. In Audition, (ed. HOY, R. and DALLOS, P.). Elsevier, NY, pp.1-30.

BERMINGHAM, N.A., HASSAN, B.A., PRICE, S.D., VOLLRATH, M.A., BEN-ARIE, N., EATOCK, R.A., BELLEN, H.J., LYSAKOWSKI, A. and ZOGHBI, H.Y. (1999). Math1: an essential gene for the generation of inner ear hair cells. Science 284: 1837-41.

BERTRAND, N., CASTRO, D.S. and GUILLEMOT, F. (2002). Proneural genes and the specification of neural cell types. Nat Rev Neurosci 3: 517-30.

BERTRAND, V., HUDSON, C., CAILLOL, D., POPOVICI, C. and LEMAIRE, P. (2003). Neural tissue in ascidian embryos is induced by FGF9/16/20, acting via a combination of maternal GATA and Ets transcription factors. Ce//115:615-27.

BLECKMANN, H., BUDELMANN, B.U. and BULLOCK, T.H. (1991). Peripheral and central nervous responses evoked by small water movements in a cephalopod. $J$ Comp Physiol [A]168: 247-57.

BOUCHARD, M., SOUABNI, A., MANDLER, M., NEUBUSER, A. and BUSSLINGER, M. (2002). Nephric lineage specification by Pax2 and Pax8. Genes Dev 16: 2958-70.

BRAZEAU, M.D. and AHLBERG, P.E. (2006). Tetrapod-like middle ear architecture in a Devonian fish. Nature 439: 318-21.

BROOKER, R., HOZUMI, K. and LEWIS, J. (2006). Notch ligands with contrasting functions: Jagged1 and Delta1 in the mouse inner ear. Development 133: 1277 86.

BRYANT, J.E., FORGE, A. and RICHARDSON, G.P. (2005). The differentiation of hair cells. In Development of the inner ear., (ed. KELLEY, M. W.WU, D. K.POPPER, A. N. and FAY, R. R.). Springer Verlag, New York, pp.158-204.

BUDELMANN, B.U. (1987). Morphological Diversity of Equilibirum Receptor Systems in Aquatic Invertebrates. In Sensory Biology of Aquatic Animals, (ed. ATEMA, J.FAY, R. R.POPPER, A. N. and TAVOLGA, W. N.). Springer Verlag, New York, pp.757-782

BUDELMANN, B.U. (1989). Hydrodynamic receptor systems in invertebrates. In The Mechanosensory LateralLine. Neurobiology and Evolution., (ed. COOMBS, S.GOERNER, P. and MUENZ, H.). Springer Verlag, Mew York, pp.607-632.

BURIGHEL, P., LANE, N.J., FABIO, G., STEFANO, T., ZANIOLO, G., CARNEVALI, M.D. and MANNI, L. (2003). Novel, secondary sensory cell organ in ascidians: in search of the ancestor of the vertebrate lateral line. J Comp Neuro/461: 23649.

BURKE, R.D., ANGERER, L.M., ELPHICK, M.R., HUMPHREY, G.W., YAGUCHI, S., KIYAMA, T., LIANG, S., MU, X., AGCA, C., KLEIN, W.H. et al. (2006). A genomic view of the sea urchin nervous system. Dev Bio/300: 434-60.

BURTON, Q., COLE, L.K., MULHEISEN, M., CHANG, W. and WU, D.K. (2004). The role of Pax2 in mouse inner ear development. Dev Bio/272: 161-75.

CALDWELL, J.C. and EBERL, D.F. (2002). Towards a molecular understanding of Drosophila hearing. J Neurobio/53: 172-89.

CANTOS, R., COLE, L.K., ACAMPORA, D., SIMEONE, A. and WU, D.K. (2000). Patterning of the mammalian cochlea. Proc Nat/ Acad Sci USA 97: 11707-13.

CHANG, W., BRIGANDE, J.V., FEKETE, D.M. and WU, D.K. (2004a). The development of semicircular canals in the inner ear: role of FGFs in sensory cristae. Development 131: 4201-11.

CHANG, W., COLE, L.K., CANTOS, R. and WU, D.K. (2004b). Molecular genetics of vestibular organ development. In The Vestibular System, vol. 19 (ed. HIGHSTEIN, S. M.FAY, R. R. and POPPER, A. N.). Springer Verlag, New York, pp.11-56

CHEN, P., JOHNSON, J.E., ZOGHBI, H.Y. and SEGIL, N. (2002). The role of Math1 in inner ear development: Uncoupling the establishment of the sensory primordium from hair cell fate determination. Development 129: 2495-2505.

CHENG, W., YANG, F., TAKANISHI, C.L. and ZHENG, J. (2007). Thermosensitive TRPV Channel Subunits Coassemble into Heteromeric Channels with Intermediate Conductance and Gating Properties. J. Gen. Physiol. 129: 101-207.

CHIANG, C.S., ANISHKIN, A. and SUKHAREV, S. (2004). Gating of the large mechanosensitive channel in situ: estimation of the spatial scale of the transition from channel population responses. Biophys J86: 2846-61.

CLACK, J.A. (2002). Patterns and processes in the early evolution of the tetrapod ear. J Neurobio/53: 251-64.

COFFIN, A., KELLEY, M.W., MANLEY, G.A. and POPPER, A.N. (2004). Evolution of sensory hair cells. In Evolution of the vertebrate auditory system, (ed. MANLEY, G. A.POPPER, A. N. and FAY, R. R.). Springer Verlag, New York pp.55-94,

COWAN, C.A., YOKOYAMA, N., BIANCHI, L.M., HENKEMEYER, M. and FRITZSCH, B. (2000). EphB2 guides axons at the midline and is necessary for normal vestibular function. Neuron 26: 417-30.

CRAMER, K.S., FRASER, S.E. and RUBEL, E.W. (2000). Embryonic origins of auditory brain-stem nuclei in the chick hindbrain. Dev Bio/224: 138-51.

CZERNY, T., BOUCHARD, M., KOZMIK, Z. and BUSSLINGER, M. (1997). The characterization of novel Pax genes of the sea urchin and Drosophila reveal an ancient evolutionary origin of the Pax2/5/8 subfamily. Mech Dev67: 179-92.

DAUDET, N. and LEWIS, J. (2005). Two contrasting roles for Notch activity in chick inner ear development: specification of prosensory patches and lateral inhibition of hair-cell differentiation. Development 132: 541-51.

DELAUNE, E., LEMAIRE, P. and KODJABACHIAN, L. (2005). Neural induction in Xenopus requires early FGF signalling in addition to BMP inhibition. Development 132: 299-310.

DEQUEANT, M.L., GLYNN, E., GAUDENZ, K., WAHL, M., CHEN, J., MUSHEGIAN, A. and POURQUIE, O. (2006). A complex oscillating network of signaling genes underlies the mouse segmentation clock. Science 314: 1595-8.

EHRET, G. and ROMAND, R. (1997). The Central Auditory System. Oxford University Press, InC, New York.

ERKMAN, L., MCEVILLY, R.J., LUO, L., RYAN, A.K., HOOSHMAND, F., O'CONNELL, S.M., KEITHLEY, E.M., RAPAPORT, D.H., RYAN, A.F. and ROSENFELD, M.G. (1996). Role of transcription factors Brn-3.1 and Brn-3.2 in auditory and visual system development. Nature 381: 603-6.

FARAGO, A.F., AWATRAMANI, R.B. and DYMECKI, S.M. (2006). Assembly of the brainstem cochlear nuclear complex is revealed by intersectional and subtractive genetic fate maps. Neuron 50: 205-18.

FAVOR, J., SANDULACHE, R., NEUHAUSER-KLAUS, A., PRETSCH, W., CHATTERJEE, B., SENFT, E., WURST, W., BLANQUET, V., GRIMES, P. SPORLE, R. et al. (1996). The mouse Pax2(1Neu) mutation is identical to a human PAX2 mutation in a family with renal-coloboma syndrome and results in developmental defects of the brain, ear, eye and kidney. ProcNat/Acad SciUSA 93: $13870-5$

FRITZSCH, B. (1992). The water-to-land transition: Evolution of the tetrapod basilar papilla, middle ear and auditory nuclei. In The Evolutionary Biology of Hearing, (ed. WEBSTER, D. B.FAY, R. R. and POPPER, A. N.). Springer Verlag, New York, pp.351-375

FRITZSCH, B. (1999). Hearing in two worlds: Theoretical and realistic adaptive changes of the aquatic and terrestrial ear for sound reception. In Comparative Hearing: Fish and Amphibians., (ed. FAY, R. R. and POPPER, A. N.). SpringerVerlag, New York, pp.15-42.

FRITZSCH, B. (2003). The ear of Latimeria chalumnae revisited. Zoology 106: 243248.

FRITZSCH, B. and BEISEL, K.W. (2004). Keeping sensory cells and evolving neurons to connect them to the brain: molecular conservation and novelties in vertebrate ear development. Brain Behav Evo/64: 182-97.

FRITZSCH, B., BEISEL, K.W. and BERMINGHAM, N.A. (2000). Developmental evolutionary biology of the vertebrate ear: conserving mechanoelectric transduction and developmental pathways in diverging morphologies. Neuroreport 11: R35-44.

FRITZSCH, B., BEISEL, K.W. and HANSEN, L.A. (2006a). The molecular basis of neurosensory cell formation in ear development: a blueprint for hair cell and sensory neuron regeneration? Bioessays 28: 1181-93. 
FRITZSCH, B., BEISEL, K.W., JONES, K., FARINAS, I., MAKLAD, A., LEE, J. and REICHARDT, L.F. (2002). Development and evolution of inner ear sensory epithelia and their innervation. J Neurobio/53: 143-56.

FRITZSCH, B. and GLOVER, J.C. (2006). Evolution of the deuterostome central nervous system: an intercalation of developmental patterning processes with cellular specification processes.. In Evolution of the Nervous System, vol. 2 (ed. KAAS, J. H.). Academic Press, Oxford, pp.1-24.

FRITZSCH, B., MATEI, V.A., NICHOLS, D.H., BERMINGHAM, N., JONES, K., BEISEL, K.W. and WANG, V.Y. (2005a). Atoh1 null mice show directed afferent fiber growth to undifferentiated ear sensory epithelia followed by incomplete fiber retention. Dev Dyn 233: 570-83.

FRITZSCH, B. and NEARY, T. (1998). The octavolateralis system of mechanosensory and electrosensory organs. In Amphibian Biology, vol. Vol 3; Sensory Perception (ed. HEATWOLE, H.). Surrey Beatty \& Sons, Chipping Norton, pp.878-922.

FRITZSCH, B., PAULEY, S. and BEISEL, K.W. (2006b). Cells, molecules and morphogenesis: the making of the vertebrate ear. Brain Res 1091: 151-71.

FRITZSCH, B., PAULEY, S., FENG, F., MATEI, V. and NICHOLS, D.H. (2006c). The evolution of the vertebrate auditory system: transformations of vestibular mechanosensory cells for sound processing is combined with newly generated central processing neurons. Int. J. Comp. Psychol. 19: 1-24.

FRITZSCH, B., PIATIGORSKY, J., TESSMAR-RAIBLE, K., JEKELY, G., GUY, K., RAIBLE, F., WITTBRODT, J. and ARENDT, D. (2005b). Ancestry of Photic and Mechanic Sensation? Science 308: 1113-1114.

FRITZSCH, B., RYAN, M., WILCZYNSKI, W., HETHERINGTON, T. and WALKOWIAK, W. (1988). The Evolution of the Amphibian Auditory System. Wiley \& Sons, New York.

FRITZSCH, B., SIGNORE, M. and SIMEONE, A. (2001). Otx1 null mutant mice show partial segregation of sensory epithelia comparable to lamprey ears. Dev Genes Evol211: 388-96.

FRITZSCH, B. and WAKE, M.H. (1988). The inner ear of gymnophione amphibians and its nerve supply: a comparative study of regressive events in a complex sensory system. Zoomorphol. 108: 210-217.

FURLONG, R.F. and GRAHAM, A. (2005). Vertebrate neurogenin evolution: longterm maintenance of redundant duplicates. Dev Genes Evo/215: 639-44.

GEHRING, W.J. (2005). New perspectives on eye development and the evolution of eyes and photoreceptors. J Hered 96: 171-84.

GILLESPIE, P.G., DUMONT, R.A. and KACHAR, B. (2005). Have we found the tip link, transduction channel and gating spring of the hair cell? Curr OpinNeurobiol 15: 389-96.

GOVINDARAJAN, V., ITO, M., MAKARENKOVA, H.P., LANG, R.A. and OVERBEEK, P.A. (2000). Endogenous and ectopic gland induction by FGF-10. Dev Bio/225: 188-200.

HAMMOND, K.L., HILL, R.E., WHITFIELD, T.T. and CURRIE, P.D. (2002). Isolation of three zebrafish dachshund homologues and their expression in sensory organs, the central nervous system and pectoral fin buds. Mech Dev112: 1839.

HAMMOND, K.L. and WHITFIELD, T.T. (2006). The developing lamprey ear closely resembles the zebrafish otic vesicle: otx 1 expression can account for all major patterning differences. Development 133: 1347-57.

HERTZANO, R., MONTCOUQUIOL, M., RASHI-ELKELES, S., ELKON, R., YUCEL, R., FRANKEL, W.N., RECHAVI, G., MOROY, T., FRIEDMAN, T.B., KELLEY, M.W. et al. (2004). Transcription profiling of inner ears from Pou4f3(ddl/ddl) identifies Gfi1 as a target of the Pou4f3 deafness gene. Hum Mol Genet 13: 2143-53.

HOLLAND, L.Z. (2005). Non-neural ectoderm is really neural: evolution of developmental patterning mechanisms in the non-neural ectoderm of chordates and the problem of sensory cell homologies. J Exp Zoolog B Mol Dev Evo/304: 304-23.

HOLLAND, N.D. (2003). Early central nervous system evolution: an era of skin brains? Nat Rev Neurosci 4: 617-27.

HULANDER, M., KIERNAN, A.E., BLOMQVIST, S.R., CARLSSON, P., SAMUELSSON, E.J., JOHANSSON, B.R., STEEL, K.P. and ENERBACK, S. (2003). Lack of pendrin expression leads to deafness and expansion of the endolymphatic compartment in inner ears of Foxi1 null mutant mice. Development 130: 2013-2025.

JACOBS, G.H., WILLIAMS, G.A., CAHILL, H. and NATHANS, J. (2007). Emergence of novel color vision in mice engineered to express a human cone photopigment. Science 315: 1723-5.

JAFAR-NEJAD, H., ACAR, M., NOLO, R., LACIN, H., PAN, H., PARKHURST, S.M. and BELLEN, H.J. (2003). Senseless acts as a binary switch during sensory organ precursor selection. Genes Dev 17: 2966-78.

JONES, C. and CHEN, P. (2007). Planar cell polarity signaling in vertebrates. Bioessays 29: 120-32.

JORGENSEN, J.M. (1989). Evolution of octavolateralis sensory cells. In The Mechanosensory Lateral Line. Neurobiology and Evolution., (ed. COOMBS, S.GOERNER, P. and MUENZ, H.). Springer Verlag, New York, pp.99-115.

KAGEYAMA, R., OHTSUKA, T., HATAKEYAMA, J. and OHSAWA, R. (2005). Roles of bHLH genes in neural stem cell differentiation. Exp Cel/ Res 306: 3438.

KAGEYAMA, R., OHTSUKA, T. and KOBAYASHI, T. (2007). The Hes gene family: repressors and oscillators that orchestrate embryogenesis. Development 134: 1243-51.

KARIS, A., PATA, I., VAN DOORNINCK, J.H., GROSVELD, F., DE ZEEUW, C.I., DE CAPRONA, D. and FRITZSCH, B. (2001). Transcription factor GATA-3 alters pathway selection of olivocochlear neurons and affects morphogenesis of the ear. J Comp Neuro/429: 615-30.

KAVALER, J., FU, W., DUAN, H., NOLL, M. and POSAKONY, J.W. (1999). An essential role for the Drosophila Pax2 homolog in the differentiation of adult sensory organs. Development 126: 2261-72.

KELLEY, M.W. (2006a). Hair cell development: Commitment through differentiation. Brain Res.

KELLEY, M.W. (2006b). Regulation of cell fate in the sensory epithelia of the inner ear. Nat Rev Neurosci 7: 837-49.

KIERNAN, A.E., PELLING, A.L., LEUNG, K.K., TANG, A.S., BELL, D.M., TEASE, C., LOVELL-BADGE, R., STEEL, K.P. and CHEAH, K.S. (2005). Sox2 is required for sensory organ development in the mammalian inner ear. Nature 434: 1031-5.

KIERNAN, A.E., XU, J. and GRIDLEY, T. (2006). The Notch Ligand JAG1 Is Required for Sensory Progenitor Development in the Mammalian Inner Ear. PLOS Genet 2: e4.

KOZMIK, Z., DAUBE, M., FREI, E., NORMAN, B., KOS, L., DISHAW, L.J., NOLL, M. and PIATIGORSKY, J. (2003). Role of Pax genes in eye evolution: a cnidarian PaxB gene uniting Pax2 and Pax6 functions. Dev Cel/5: 773-85.

KOZMIK, Z., HOLLAND, N.D., KALOUSOVA, A., PACES, J., SCHUBERT, M. and HOLLAND, L.Z. (1999). Characterization of an amphioxus paired box gene, AmphiPax2/5/8: developmental expression patterns in optic support cells, nephridium, thyroid-like structures and pharyngeal gill slits, but not in the midbrain-hindbrain boundary region. Development 126: 1295-304.

KRELOVA, J., HOLLAND, L.Z., SCHUBERT, M., BURGTORF, C., BENES, V. and KOZMIK, Z. (2002). Functional equivalency of amphioxus and vertebrate Pax258 transcription factors suggests that the activation of mid-hindbrain specific genes in vertebrates occurs via the recruitment of Pax regulatory elements. Gene 282: 143-50.

KWAN, K.Y., ALLCHORNE, A.J., VOLLRATH, M.A., CHRISTENSEN, A.P., ZHANG, D.S., WOOLF, C.J. and COREY, D.P. (2006). TRPA1 contributes to cold, mechanical and chemical nociception but is not essential for hair-cell transduction. Neuron 50: 277-89.

LADHER, R.K., WRIGHT, T.J., MOON, A.M., MANSOUR, S.L. and SCHOENWOLF, G.C. (2005). FGF8 initiates inner ear induction in chick and mouse. Genes Dev 19: 603-13.

LANFORD, P.J. and KELLEY, M.W. (2005). Notch signaling and cell fate determination in the vertebrate inner ear. In Development of the Inner Ear, vol. SHAR 26 (ed. KELLEY, M. W.K., W. D.POPPER, A. N. and FAY, R. R.). Springer, New York, NY, pp.122-157.

LEE, H.H. and FRASCH, M. (2004). Survey of forkhead domain encoding genes in the Drosophila genome: Classification and embryonic expression patterns. Dev Dyn 229: 357-66.

LEE, Y.S., LIU, F. and SEGIL, N. (2006). A morphogenetic wave of p27Kip1 transcription directs cell cycle exit during organ of Corti development. Development 133: 2817-26.

LEWIS, E.R., LEVERENZ, E.L. and BIALEK, W.S. (1985). The vertebrate innerear. CRC Press, Boca Raton.

LI, S., PRICE, S.M., CAHILL, H., RYUGO, D.K., SHEN, M.M. and XIANG, M. (2002). 
Hearing loss caused by progressive degeneration of cochlear hair cells in mice deficient for the Barhl1 homeobox gene. Development 129: 3523-32.

LIN, S.Y. and COREY, D.P. (2005). TRP channels in mechanosensation. Curr Opin Neurobio/15: 350-7.

LITSIOU, A., HANSON, S. and STREIT, A. (2005). A balance of FGF, BMP and WNT signalling positions the future placode territory in the head. Development 132: 4051-62.

LOWE, C.J., WU, M., SALIC, A., EVANS, L., LANDER, E., STANGE-THOMANN, N., GRUBER, C.E., GERHART, J. and KIRSCHNER, M. (2003). Anteroposterior patterning in hemichordates and the origins of the chordate nervous system. Cel/113: 853-65.

MAKARENKOVA, H.P., ITO, M., GOVINDARAJAN, V., FABER, S.C., SUN, L., MCMAHON, G., OVERBEEK, P.A. and LANG, R.A. (2000). FGF10 is an inducer and Pax6 a competence factor for lacrimal gland development. Development 127: 2563-72.

MANSOUR, S.L. (1994). Targeted disruption of int-2 (fgf-3) causes developmental defects in the tail and inner ear. Mol Reprod Dev 39: 62-7; discussion 67-8.

MAROON, H., WALSHE, J., MAHMOOD, R., KIEFER, P., DICKSON, C. and MASON, I. (2002). Fgf3 and Fgf8 are required together for formation of the otic placode and vesicle. Development 129: 2099-108.

MARTINEZ-MONEDERO, R., CORRALES, C.E., CUAJUNGCO, M.P., HELLER, S. and EDGE, A.S. (2006). Reinnervation of hair cells by auditory neurons after selective removal of spiral ganglion neurons. J Neurobio/66: 319-31.

MASSA, S.M., XIE, Y., YANG, T., HARRINGTON, A.W., KIM, M.L., YOON, S.O., KRAEMER, R., MOORE, L.A., HEMPSTEAD, B.L. and LONGO, F.M. (2006). Small, nonpeptide p75NTR ligands induce survival signaling and inhibit proNGFinduced death. JNeurosci26: 5288-300.

MASSAGUE, J., SEOANE, J. and WOTTON, D. (2005). Smad transcription factors. Genes Dev 19: 2783-810.

MATEI, V., PAULEY, S., KAING, S., ROWITCH, D., BEISEL, K.W., MORRIS, K., FENG, F., JONES, K., LEE, J. and FRITZSCH, B. (2005). Smaller inner ear sensory epithelia in Neurog 1 null mice are related to earlier hair cell cycle exit. Dev Dyn 234: 633-50.

MAZET, F., HUTT, J.A., MILLOZ, J., MILLARD, J., GRAHAM, A. and SHIMELD, S.M. (2005). Molecular evidence from Ciona intestinalis for the evolutionary origin of vertebrate sensory placodes. Dev Bio/282: 494-508.

MAZET, F. and SHIMELD, S.M. (2005). Molecular evidence from ascidians for the evolutionary origin of vertebrate cranial sensory placodes. J Exp Zoolog B Mol Dev Evo/304: 340-6.

MCKIMMIE, C., WOERFEL, G. and RUSSELL, S. (2005). Conserved genomic organisation of Group B Sox genes in insects. BMC Genet 6: 26.

MEINHARDT, H. (2004). Different strategies for midline formation in bilaterians. Nat Rev Neurosci5: 502-10.

MILLIMAKI, B.B., SWEET, E.M., DHASON, M.S. and RILEY, B.B. (2007). Zebrafish atoh1 genes: classic proneural activity in the inner ear and regulation by Fgf and Notch. Development 134: 295-305.

MONDAL, S., IVANCHUK, S.M., RUTKA, J.T. and BOULIANNE, G.L. (2007). Sloppy paired $1 / 2$ regulate glial cell fates by inhibiting $\mathrm{Gcm}$ function. Glia 55: 282-93.

MONTCOUQUIOL, M., SANS, N., HUSS, D., KACH, J., DICKMAN, J.D., FORGE, A., RACHEL, R.A., COPELAND, N.G., JENKINS, N.A., BOGANI, D. et al. (2006). Asymmetric localization of Vangl2 and Fz3 indicate novel mechanisms for planar cell polarity in mammals. JNeurosci 26: 5265-75.

MORSLI, H., TUORTO, F., CHOO, D., POSTIGLIONE, M.P., SIMEONE, A. and WU, D.K. (1999). Otx1 and Otx2 activities are required for the normal development of the mouse inner ear. Development 126: 2335-43.

NORNES, H.O., DRESSLER, G.R., KNAPIK, E.W., DEUTSCH, U. and GRUSS, P. (1990). Spatially and temporally restricted expression of Pax2 during murine neurogenesis. Development 109: 797-809.

O'BRIEN, E.K. and DEGNAN, B. (2003). Expression of Pax258 in the gastropod statocyst: insights into the antiquity of metazoan geosensory organs. Evol Dev 5: 572-578.

O'BRIEN, E.K. and DEGNAN, B.M. (2002). Developmental expression of a class IV POU gene in the gastropod Haliotis asinina supports a conserved role in sensory cell development in bilaterians. Dev Genes Evo/212: 394-8.
O'HAGAN, R., CHALFIE, M. and GOODMAN, M.B. (2005). The MEC-4 DEG/ENaC channel of Caenorhabditis elegans touch receptor neurons transduces mechanical signals. Nat Neurosci 8: 43-50

O'NEILL, P., MCCOLE, R.B. and BAKER, C.V. (2006). A molecular analysis of neurogenic placode and cranial sensory ganglion development in the shark, Scyliorhinus canicula. Dev Biol.

OHUCHI, H., YASUE, A., ONO, K., SASAOKA, S., TOMONARI, S., TAKAGI, A., ITAKURA, M., MORIYAMA, K., NOJI, S. and NOHNO, T. (2005). Identification of cis-element regulating expression of the mouse Fgf10 gene during inner ear development. Dev Dyn 233: 177-87.

OHYAMA, T., MOHAMED, O.A., TAKETO, M.M., DUFORT, D. and GROVES, A.K. (2006). Wnt signals mediate a fate decision between otic placode and epider mis. Development 133: 865-75.

PAULEY, S., LAI, E. and FRITZSCH, B. (2006). Foxg1 is required for morphogenesis and histogenesis of the mammalian inner ear. Dev Dyn 235: 2470-82.

PAULEY, S., MATEI, V., BEISEL, K.W. and B, F. (2005). Wiring the ear to the brain: the molecular basis of neurosensory development, differentiation and survival. In Development of the inner ear, (ed. KELLEY, M. W.WU, D. K.POPPER, A. N. and FAY, R. R.). Springer, New York, pp.85-122.

PAULEY, S., WRIGHT, T.J., PIRVOLA, U., ORNITZ, D., BEISEL, K. and FRITZSCH, B. (2003). Expression and function of FGF10 in mammalian inner ear development. Dev Dyn 227: 203-15.

PFEFFER, P.L., GERSTER, T., LUN, K., BRAND, M. and BUSSLINGER, M. (1998). Characterization of three novel members of the zebrafish Pax2/5/8 family: dependency of Pax5 and Pax8 expression on the Pax2.1 (noi) function. Development 125: 3063-74.

PIRVOLA, U., SPENCER-DENE, B., XING-QUN, L., KETTUNEN, P., THESLEFF, I., FRITZSCH, B., DICKSON, C. and YLIKOSKI, J. (2000). FGF/FGFR-2(IIIb) signaling is essential for inner ear morphogenesis. JNeurosci20: 6125-34.

PONNIO, T., BURTON, Q., PEREIRA, F.A., WU, D.K. and CONNEELY, O.M. (2002). The nuclear receptor Nor-1 is essential for proliferation of the semicircular canals of the mouse inner ear. Mol Cel/ Bio/22: 935-45.

PUJADES, C., KAMAID, A., ALSINA, B. and GIRALDEZ, F. (2006). BMP-signaling regulates the generation of hair-cells. Dev Bio/292: 55-67.

PUTNAM, N.H., SRIVASTAVA, M., HELLSTEN, U., DIRKS, B., CHAPMAN, J., SALAMOV, A., TERRY, A., SHAPIRO, H., LINDQUIST, E., KAPITONOV, V.V. et al. (2007). Sea anemone genome reveals ancestral eumetazoan gene repertoire and genomic organization. Science 317: 86-94.

RAFT, S., NOWOTSCHIN, S., LIAO, J. and MORROW, B.E. (2004). Suppression of neural fate and control of inner ear morphogenesis by Tbx1. Development 131: $1801-12$

RILEY, B.B. (2003). Genes controlling the development of the zebrafish inner ear and hair cells. Curr Top Dev Bio/57: 357-88.

RUBEN, R.J. (1967). Development of the inner ear of the mouse: a radioautographic study of terminal mitoses. Acta OtolaryngoSuppl 220:1-44.

SALMINEN, M., MEYER, B.I., BOBER, E. and GRUSS, P. (2000). Netrin 1 is required for semicircular canal formation in the mouse inner ear. Development 127: 13-22.

SCHLOSSER, G. (2006). Induction and specification of cranial placodes. Dev Biol 294: 303-51.

SEIPEL, K., YANZE, N. and SCHMID, V. (2004). Developmental and evolutionary aspects of the basic helix-loop-helix transcription factors Atonal-like 1 and Achaete-scute homolog 2 in the jellyfish. Dev Bio/269: 331-45.

SIDI, S., FRIEDRICH, R.W. and NICOLSON, T. (2003). NompC TRP channel required for vertebrate sensory hair cell mechanotransduction. Science 301: 96-9.

SIMIONATO, E., LEDENT, V., RICHARDS, G., THOMAS-CHOLLIER, M., KERNER, P., COORNAERT, D., DEGNAN, B.M. and VERVOORT, M. (2007). Origin and diversification of the basic helix-loop-helix gene family in metazoans: insights from comparative genomics. BMC Evol BiO/7: 33.

SODERGREN, E.WEINSTOCK, G.M.DAVIDSON, E.H.CAMERON, R.A.GIBBS, R.A.ANGERER, R.C.ANGERER, L.M.ARNONE, M.I.BURGESS, D.R.BURKE, R.D. etal. (2006). The genome of the sea urchin Strongylocentrotus purpuratus. Science 314: 941-52.

STEENKAMP, E.T., WRIGHT, J. and BALDAUF, S.L. (2006). The protistan origins 
of animals and fungi. Mol Biol Evol23: 93-106.

STEVENS, C.B., DAVIES, A.L., BATTISTA, S., LEWIS, J.H. and FEKETE, D.M. (2003). Forced activation of Wnt signaling alters morphogenesis and sensory organ identity in the chicken inner ear. Dev Bio/261: 149-64.

SUKHAREV, S. and COREY, D.P. (2004). Mechanosensitive Channels: multiplicity of families and gating paradigms. Science's STKE219: 1-24.

SUTHERLAND, D., SAMAKOVLIS, C. and KRASNOW, M.A. (1996). branchless encodes a Drosophila FGF homolog that controls tracheal cell migration and the pattern of branching. Cel/87: 1091-101.

SWANTEK, D. and GERGEN, J.P. (2004). Ftz modulates Runt-dependent activation and repression of segment-polarity gene transcription. Development 131 : 2281-90.

SYNTICHAKI, P. and TAVERNARAKIS, N. (2004). Genetic models of mechanotransduction: the nematode Caenorhabditis elegans. Physio/Rev84: 1097-153.

TESSAROLLO, L., COPPOLA, V. and FRITZSCH, B. (2004). NT-3 replacement with brain-derived neurotrophic factor redirects vestibular nerve fibers to the cochlea. JNeurosci24: 2575-84.

TODI, S.V., FRANKE, J.D., KIEHART, D.P. and EBERL, D.F. (2005). Myosin VIIA defects, which underlie the Usher 1B syndrome in humans, lead to deafness in Drosophila. Curr Bio/15: 862-8.

TORBAN, E., ECCLES, M.R., FAVOR, J. and GOODYER, P.R. (2000). PAX2 suppresses apoptosis in renal collecting duct cells. Am J Patho/157: 833-42.

TORRES, M. and GIRALDEZ, F. (1998). The development of the vertebrate inner ear. Mech Dev 71: 5-21.

TORRES, M., GOMEZ-PARDO, E. and GRUSS, P. (1996). Pax2 contributes to inner ear patterning and optic nerve trajectory. Development 122: 3381-91.

UCHIKAWA, M., ISHIDA, Y., TAKEMOTO, T., KAMACHI, Y. and KONDOH, H. (2003). Functional analysis of chicken Sox2 enhancers highlights an array of diverse regulatory elements that are conserved in mammals. Dev Ce//4: 50919.

WADA, H., SAIGA, H., SATOH, N. and HOLLAND, P.W. (1998). Tripartite organization of the ancestral chordate brain and the antiquity of placodes: insights from ascidian Pax-2/5/8, Hox and Otx genes. Development 125: 1113-22.

WALLIS, D., HAMBLEN, M., ZHOU, Y., VENKEN, K.J., SCHUMACHER, A.,
GRIMES, H.L., ZOGHBI, H.Y., ORKIN, S.H. and BELLEN, H.J. (2003). The zinc finger transcription factor Gfi1, implicated in lymphomagenesis, is required for inner ear hair cell differentiation and survival. Development 130: 221-32.

WANG, V.Y., HASSAN, B.A., BELLEN, H.J. and ZOGHBI, H.Y. (2002). Drosophila atonal fully rescues the phenotype of Math1 null mice: new functions evolve in new cellular contexts. Curr Bio/12: 1611-6.

WANG, V.Y., ROSE, M.F. and ZOGHBI, H.Y. (2005). Math1 expression redefines the rhombic lip derivatives and reveals novel lineages within the brainstem and cerebellum. Neuron 48: 31-43.

WANG, Y. and NATHANS, J. (2007). Tissue/planar cell polarity in vertebrates: new insights and new questions. Development 134: 647-58.

WESTON, M.D., PIERCE, M.L., ROCHA-SANCHEZ, S., BEISEL, K.W. and SOUKUP, G.A. (2006). MicroRNA gene expression in the mouse inner ear. Brain Res 1111: 95-104.

WRIGHT, T.J., HATCH, E.P., KARABAGLI, H., KARABAGLI, P., SCHOENWOLF, G.C. and MANSOUR, S.L. (2003). Expression of mouse fibroblast growth factor and fibroblast growth factor receptor genes during early inner ear development. Dev Dyn 228: 267-72.

WRIGHT, T.J. and MANSOUR, S.L. (2003). Fgf3 and Fgf10 are required for mouse otic placode induction. Development 130: 3379-90.

XIANG, M., MAKLAD, A., PIRVOLA, U. and FRITZSCH, B. (2003). Brn3c null mutant mice show long-term, incomplete retention of some afferent inner ear innervation. BMC Neurosci 4: 2.

XU, H., VIOLA, A., ZHANG, Z., GERKEN, C.P., LINDSAY-ILLINGWORTH, E.A. and BALDINI, A. (2007). Tbx1 regulates population, proliferation and cell fate determination of otic epithelial cells. Dev Bio/302: 670-82.

ZHANG, X., IBRAHIMI, O.A., OLSEN, S.K., UMEMORI, H., MOHAMMADI, M. and ORNITZ, D.M. (2006). Receptor specificity of the fibroblast growth factor family. The complete mammalian FGF family. J Biol Chem 281: 15694-700.

ZOU, D., SILVIUS, D., RODRIGO-BLOMQVIST, S., ENERBACK, S. and XU, P.X. (2006). Eya1 regulates the growth of otic epithelium and interacts with Pax2 during the development of all sensory areas in the inner ear. Dev Bio/298: 43041.

Published Online: 27th August 2007 


\section{Related, previously published Int. J. Dev. Biol. articles}

See our Special Issue Ear Development edited by Fernando Giraldez and Bernd Fritzsch at: http://www.ijdb.ehu.es/web/contents.php?vol=51\&issue=6-7

Hox and ParaHox genes in Nemertodermatida, a basal bilaterian clade

Eva Jiménez-Guri, Jordi Paps, Jordi García-Fernández and Emili Saló

Int. J. Dev. Biol. (2006) 50: 675-679

Evolutionary embryology resurrected in Japan with a new molecular basis: Nori Satoh and the history of ascidian studies originating in Kyoto during the 20th century

Shigeru Kuratani, Hiroshi Wada, Rie Kusakabe And Kiyokazu Agata

Int. J. Dev. Biol. (2006) 50: 451-454

Posterior expression of nanos orthologs during embryonic and larval development of the anthozoan Nematostella vectensis

Raquel Torras and Sergio González-Crespo

Int. J. Dev. Biol. (2005) 49: 895-899

From phenotypic to molecular polymorphisms involved in naturally occurring variation of plant development Carlos Alonso-Blanco, Belén Mendez-Vigo and Maarten Koornneef

Int. J. Dev. Biol. (2005) 49: 717-732

Plastids unleashed: their development and their integration in plant development

Enrique Lopez-Juez and Kevin A. Pyke

Int. J. Dev. Biol. (2005) 49: 557-577

Notch in vertebrates - molecular aspects of the signal

Ken-Ichi Katsube and Kei Sakamoto

Int. J. Dev. Biol. (2005) 49: 369-374

Cubozoan jellyfish: an Evo/Devo model for eyes and other sensory systems

Joram Piatigorsky and Zbynek Kozmik

Int. J. Dev. Biol. (2004) 48: 719-729

Historical perspective on the development and evolution of eyes and photoreceptors

Walter J. Gehring

Int. J. Dev. Biol. (2004) 48: 707-717

\section{Evolving eyes}

Russell D. Fernald

Int. J. Dev. Biol. (2004) 48: 701-705 